\title{
Effects of female body mass index on the outcome of in vitro fertilization/intracytoplasmic sperm injection or intrauterine insemination
}

\author{
Philippe Merviel*, Anne-Solenn Jacamon, Sarah Bouée, Marie-Thérèse Le Martelot, Sylvie Roche, Jean-Jacques Chabaud, Hortense \\ Drapier, Aurore Perrin and Damien Beauvillard
}

ART Center, Brest University Hospital, 2 avenue Foch, F-29200 Brest, France

\begin{abstract}
Background: Many studies have suggested that female obesity has an impact on oocyte quality, embryo quality, and endometrial maturation in couples undergoing in vitro fertilization/intracytoplasmic sperm injection (IVF/ICSI). In contrast, there are few data on the management of intrauterine insemination (IUI) in obese women. The objectives of the present study were to evaluate the clinical pregnancy and live birth rates in IVF/ICSI and IUI for overweight or obese women and to determine positive or negative predictive factors for pregnancy.

Method: We analyzed long GnRH agonist or GnRH antagonist protocols with FSH/hMG for IVF/ICSI, and FSH/hMG alone for IUI. We classified the women into three groups: normal weight, overweight, and obesity. The latter group was divided into two obesity subgroups: class 1 and class $2 / 3$. We recorded data on the patients' demographic, stimulation cycles, embryo cultures, and ongoing pregnancies obtained. For IVF/ICSI and IUI, we performed a univariate analysis of factors that were predictive of pregnancy and then selected a number for inclusion in a multivariate analysis.

Results: The study included 1153 IVF/ICSI cycles and 541 IUI cycles. The clinical pregnancy and live birth rates in IVF/ICSI did not vary as a function of the female BMI. In IUI, the clinical pregnancy and live birth rates were significantly higher among obese women $(21.6 \%$ and $17.7 \%$, respectively) than among women of normal weight $(12.2 \%$ and $9.3 \%$, respectively; $<<0.05)$. In IVF/ICSI and IUI, we did not observe an association between the spontaneous miscarriage rate and the BMI. In a univariate analysis, several predictive factors were found for IVF/ICSI and IUI. However, in a multivariate analysis, pregnancy in IVF/ICSI was notably predicted by the number of embryos obtained ( $\geq 5$ ), whereas the absence of pregnancy in IUI was notably predicted by a monofollicular response to ovarian stimulation ( $<<0.001$ for both).

Conclusions: Our study did not find differences in clinical pregnancy and live birth rates as a function of female BMI in IVF/ICSI, and even evidenced higher rates among obese women in IUI. Nevertheless, women should be encouraged to lose weight if allowed by the setting and their age; this may decrease the incidence of obstetric complications during assisted reproductive technology programs.
\end{abstract}

\section{Introduction}

Infertility is defined by the WHO as failure to achieve a clinical pregnancy (CP) after 12 months or more of regular unprotected sexual intercourse [1]. The prevalence of infertility ranges from $12 \%$ to $24 \%$, depending on the study $[2,3]$. The body mass index (BMI) corresponds to the weight (in $\mathrm{kg}$ ) divided by the height (in $\mathrm{m}$ ) squared. Underweight is defined as a BMI below $18.5 \mathrm{~kg} / \mathrm{m}^{2}$, normal weight corresponds to a BMI of between 18.5 and $24.9 \mathrm{~kg} / \mathrm{m}^{2}$, and overweight corresponds to a BMI of between 25 to $29.9 \mathrm{~kg} / \mathrm{m}^{2}$. Moderate (class 1) obesity (Ob1) is defined as a BMI of 30 to $34.9 \mathrm{~kg} / \mathrm{m}^{2}$, severe (class II) obesity (Ob2) corresponds to a BMI of between 35 and $39.9 \mathrm{~kg} / \mathrm{m}^{2}$, and morbid (class III) obesity (Ob3) is defined as a BMI of $40 \mathrm{~kg} / \mathrm{m}^{2}$ or more. The time to pregnancy is longer for obese women. Wise et al. compared percycle fecundability ratios (FR) as a function of the BMI [4]. The results highlighted a longer time to pregnancy in overweight women (FR: 0.83 ; $95 \%$ confidence interval (CI) [0.70-100]), obese women (FR: 0.75; 95\%CI [0.58-0.97]) and morbidly obese women (FR: 0.61; 95\%CI [0.420.88]) than in women with a normal BMI. Hassan et al. [5] showed that a female BMI $>25 \mathrm{~kg} / \mathrm{m}^{2}$ was associated with a greater frequency of fertility disorders (risk ratio(RR): 6.9, $\mathrm{p}<0.001$ ). Moreover, obesity is related to female age (another negative factor for fertility), with a frequency of $2.3 \%$ between 15 and 24 but $12 \%$ between 35 and 44 [6]. At the age of 30 (the current age at first pregnancy), obesity is present in $9 \%$ of couples.

The literature data have broadly evidenced the impact of female obesity on oocyte quality, embryo quality and the endometrium in women in in vitro fertilization/intracytoplasmic sperm injection (IVF/ ICSI) programs [7]. Obesity impacts the ovarian response, requiring higher doses of gonadotrophin and a longer duration of stimulation [8]. Obesity is also associated with poor oocyte quality, with an increase in the risk of aneuploidy; impaired endometrial receptivity, and lower implantation rates [9]. In IVF, obesity is known to be associated with abnormally low pregnancy rates $[10,11]$. However, there are very few

${ }^{\star}$ Correspondence to: Philippe MERVIEL, M.D., Ph. D., Department of Gynecology, Obstetrics and Reproductive Medicine, CHRU Brest - Hospital Morvan, 2 avenue Foch, France, E-mail: philippe.merviel@chu-brest.fr

Key words: in vitro fertilization/intracytoplasmic sperm injection, intrauterine insemination, body mass index, pregnancy, predictive factors

Received: May 15, 2020; Accepted: July 08, 2020; Published: July 15, 2020 
literature data on the management of intrauterine insemination (IUI) in obese women, and the published studies have given contrasting results. Wang et al. [12] performed a retrospective study of 2040 women having undergone IUI. Fecundity was defined as the probability of obtaining at least one pregnancy after IUI (corresponding to 2 to 4 treatment cycles, for Wang et al.'s center). The results highlighted a significantly higher fecundity rate in obese women than in women with a normal BMI $(\mathrm{OR}=1.79$ [95\%CI: 1.27-2.52]). The difference was still significant after adjustment for confounding factors. In a study of an IUI program by Dodson et al. [13], the association between obesity and fecundity was not significant [29]. Merviel et al. reached the same conclusion [14].

The objective of the present study was to assess the impact of female overweight and obesity on the $\mathrm{CP}$ and live birth rates in IVF/ ICSI and in IUI, and to identify positive or negative predictive factors for pregnancy.

\section{Material and methods}

All the couples enrolled in the IVF/ICSI or IUI programs in our ART center underwent the same infertility assessment. For the women, this included hormone blood tests on the second or third day of the menstrual cycle (including serum levels of FSH, LH, estradiol (E2), prolactin, and $\mathrm{AMH}$ ), an ultrasound scan of the pelvis, and hysterosalpingography (followed by coelioscopy and/or hysteroscopy if the results were abnormal). For the men, the assessment included a spermogram and a sperm motility test. All the hormone blood tests and sperm examinations were performed in the same laboratory.

The main inclusion criteria were physician-diagnosed infertility, female age 18 to 42 , male age 18 to 59 , and written consent to infertility treatment. Given that the couples had already consented to exploitation of their personal medical data and in line with the French legislation on studies of routine medical care, approval by an institutional review board was not required. The main exclusion criteria were ovarian insufficiency (AMH $<0.5 \mathrm{ng} / \mathrm{ml}$ and/or FSH $>15 \mathrm{IU} / \mathrm{l})$, severe abnormality of the uterine cavity (synechiae or diffuse adenomyosis), irreversible azoospermia (according to a testicular biopsy), and globozoospermia. We excluded cycles involving donor gametes or embryos.

\section{The IVF/ICSI procedure}

Couples underwent various controlled ovarian stimulation protocols (depending on the woman's profile and the physician's clinical preferences), including long $\mathrm{GnRH}$ agonist protocols or antagonist protocols. For long GnRH agonist use, triptorelin was most often administered (Decapepty ${ }^{\circledR}$, Ipsen Pharma, Paris, France) on day 20 of the previous cycle at a dose of $0.1 \mathrm{mg}$ per day, followed 14 days later with half an ampule of triptorelin (0.05 mg per day) and FSH (Fostimon ${ }^{\circledR}$, Genevrier, Sophia-Antipolis, France; Gonal- $\mathrm{F}^{\circledR}$, Merck, Lyon, France; Puregon $^{\circledR}$, MSD, Levallois-Perret, France) or hMG (Menopur ${ }^{\circledR}$, Ferring SAS, St Prex, Switzerland). For antagonist protocols, stimulation with FSH or hMG started on day 2 of the cycle, with the initiation of ganirelix (Orgalutran $^{\circledR}$, MSD, Levallois-Perret, France) 0.25 mg per day when the follicle size exceeded $14 \mathrm{~mm}$ or when the estradiol (E2) level was over $400 \mathrm{pg} / \mathrm{mL}$. The gonadotropin (FSH or hMG) doses used for controlled ovarian stimulation were adjusted after the first evaluation on day 5 (in antagonist protocols) or day 7 (in agonist protocols) of gonadotropin administration. The evaluation combined hormone assays (estradiol$17 \beta, \mathrm{LH}$, and progesterone) with a vaginal ultrasound assessment of the number and size of follicles and endometrial maturation. This assessment was repeated every two or three days, depending on the follicular growth. When at least three follicles had achieved a diameter $\geq 17 \mathrm{~mm}$, the endometrium had matured to a thickness of $>7 \mathrm{~mm}$, and a triple-line pattern was observed, a dose of $250 \mu \mathrm{g}$ of recombinant human chorionic gonadotropin-rhCG (Ovitrelle ${ }^{\circledR}$, Merck, Lyon, France) was administered and an oocyte trigger was performed 35 hours after hCG administration. Luteal phase supplementation consisted of $400 \mathrm{mg}$ per day of intravaginal micronized progesterone (Utrogestan ${ }^{\circledR}$; Besins International, Paris, France) from the evening of oocyte retrieval until the $\beta$-hCG assay two weeks later.

In the ICSI procedure, the cumulus and corona radiata were removed mechanically under a dissecting microscope, after exposure to $0.5 \%$ hyaluronidase (Sigma-Aldrich, St Louis, USA) for $30 \mathrm{~s}$. The partner's sperm was analyzed and then prepared for ICSI [15]. After $18 \mathrm{~h}$ of incubation at $37^{\circ} \mathrm{C}$ in a humidified atmosphere with $5 \% \mathrm{CO}_{2}$, oocytes were examined for the presence of two pronuclei as a sign of fertilization. The resulting embryos were cultured up to day 3 or 5. Adequate cleaved embryos were defined as those with (i) normalsized, normally shaped blastomeres, and (ii) a fragmentation rate of $10 \%$ or less [16]. Blastocysts were evaluated according to Gardner's classification [17]. One or two "best" embryos were transferred in utero on day 2-3 or day 5, using a Frydman catheter (CCD Laboratories, Paris, France). Other good-quality embryos were cryopreserved. The oocyte or embryo "freeze-all" events were decided in cases with (i) an elevated (> $1.5 \mathrm{ng} / \mathrm{ml}$ ) plasma progesterone level on the hCG day, (ii) ovarian hyperstimulation $(>3500 \mathrm{pg} / \mathrm{ml})$, or (ii) a lack of spermatozoids on the retrieval day.

\section{The IUI procedure}

Ovarian stimulation with gonadotropin was performed for each IUI cycle. The treatment began on the second day of the cycle and continued until ovulation was triggered or a LH surge-initiating rise was observed. We administered urinary FSH $\left(\right.$ Fostimon $\left.^{\circledR}\right)$, recombinant FSH (Gonal$\mathrm{F}^{\circledR}$, Puregon ${ }^{\circledR}$ ), or human menopausal gonadotrophin $\left(\right.$ Menopur $\left.^{\circledR}\right)$. A GnRH agonist or antagonist was never used during these cycles. The initial dose of gonadotropin depended on the woman's hormone profile, age, and number of previous IUI attempts. The initial dose was maintained until the first evaluation day (day 7 of treatment) and was then adjusted as a function of the ovarian response. When no more than three follicles had reached a diameter $\geq 17 \mathrm{~mm}$, the endometrium had matured (thickness $>7 \mathrm{~mm}$ ), and a triple line pattern was observed, the ovulation was triggered with a subcutaneous injection of 250 $\mu \mathrm{g}$ of recombinant human chorionic gonadotrophin (Ovitrelle ${ }^{\circledR}$ ). Insemination was performed two days later, i.e. 39 hours after the hCG injection. When an LH surge-initiating rise was observed, we performed the insemination on the following day.

On the insemination day, the partner's sperm was collected (after 48 to 72 hours of abstinence) at the laboratory two hours before the insemination. The spermatozoa were separated from the seminal liquid by centrifugation on a discontinuous density gradient column (Puresperm ${ }^{\circledR}$, Nidacon, Sweden), as described previously [14]. For the insemination itself, we used a catheter to slowly inject 0.2 to $0.4 \mathrm{ml}$ of the sperm preparation into the uterine cavity. The patient was treated with micronized progesterone (Utrogestan ${ }^{\circledR}, 400 \mathrm{mg}$ daily) for the following two weeks, until the $\beta$-hCG assay.

In our IVF/ICSI or IUI programs, CP was confirmed by ultrasound imaging 6-8 weeks after embryo transfer, and a $\beta$-hCG level above 1000 IU/L. An ongoing pregnancy was defined as pregnancy at more than 12 weeks of amenorrhea (WA). The miscarriage ratio was calculated relative to the number of clinical pregnancies after the first trimester. The live birth rate was defined as a live birth later than 24 WA. In the present study, each couple went through a single IVF/ICSI or IUI cycle. 
All the demographic, clinical and laboratory data from each cycle were examined as a function of the BMI category: normal weight (NW: BMI $=18.5$ to $\left.24.9 \mathrm{~kg} / \mathrm{m}^{2}\right)$, overweight $\left(\mathrm{OW}: \mathrm{BMI}=25\right.$ to $\left.29.9 \mathrm{~kg} / \mathrm{m}^{2}\right)$, obesity (Ob: BMI $\geq 30 \mathrm{~kg} / \mathrm{m}^{2}$ overall, or divided into Ob1 (30 to 34.9) and $\mathrm{Ob} 2-3$ (BMI $\geq 35 \mathrm{~kg} / \mathrm{m}^{2}$ ) subgroups). The primary study outcome in the various BMI groups was the CP rate per oocyte retrieved. Cycle cancellation was assessed for the cohort during the ovarian stimulation and the embryo culture periods.

\section{Statistical analysis}

Continuous variables were quoted as the mean \pm SD or (for nonnormally distributed data) the median (range). Categorical variables were quoted as the number (percentage). Differences between groups of patients were assessed with Student's test or Pearson's chi-squared test. Logistic or Poisson regression was used to calculate the unadjusted and adjusted univariate and multivariate adjusted odds ratios (ORs) [95\%CI] for CPs. The NW group served as the reference category. For IVF/ICSI procedures, the multivariate analysis arbitrarily included female age (above vs. below the age of 34), female tobacco use, couple primary infertility, the number of oocytes retrieved ( 9 or more vs. less than 9), and the number of embryos obtained (5 or more vs. less than 5). For IUI procedures, the multivariate analysis arbitrarily included female age (above vs. below the age of 34), female tobacco use, primary infertility, a monofollicular response to ovarian stimulation, and the sperm count on the day of insemination ( 5 million or more vs. less than 5 million). All analyses were performed using Microsoft ${ }^{\circledR}$ Excel software (Microsoft Corporation, Redmond, WA, USA) and the XLSTAT ${ }^{\circledR}$ add- on (Addinsoft, Paris, France). The threshold for statistical significance was set to $\mathrm{p}<0.05$.

\section{Results}

We studied a total of 1153 IVF/ICSI cycles: 652 in the NW group, 309 in the OW group, and 192 in the Ob group. The women's demographic data are summarized in Table 1 . It is noteworthy that female and male tobacco use was more prevalent in the OW and $\mathrm{OB}$ groups than in the NW group, with a particularly high value among women in the Ob1 subgroup. The male BMI varied in the same way as the female BMI. Primary infertility was less common in the Ob group than in the NW group, due to a significant difference in the Ob2 subgroup. The stimulations, embryo culture, and outcomes of the embryo transfers are summarized in Table 2. The total dose of gonadotrophin and the duration of stimulation were significantly greater in the Ob group than in the NW group; this was particularly true in the Ob1 group for the total dose of gonadotrophin and for both the Ob1 and Ob2 subgroups for the duration of stimulation. The endometrial thickness was significantly greater in the $\mathrm{OW}$ and $\mathrm{Ob}$ groups than in the NW group. The highest cycle cancellation rate during stimulation was noted in the Ob2 subgroup (12.7\%), although the differences with the NW, OW and Ob groups were not statistically significant.

The ART cycles resulted in 608 oocyte retrievals in the NW group, 282 in the OW group, and 177 in the Ob group. The numbers of mature oocytes and embryos obtained were significantly lower in the $\mathrm{Ob}$ group than in the NW group. ICSI procedures were significantly

Table 1. Demographic data for the IVF/ICSI population

\begin{tabular}{|c|c|c|c|c|c|c|c|}
\hline & NW women & OW women & Ob women & $\begin{array}{c}p \\
\text { (NW-OW) } \\
(\mathrm{NW}-\mathrm{Ob})\end{array}$ & Ob1 women & Ob2-3 women & $\begin{array}{c}p \\
\text { (NW-Ob1) } \\
\text { (NW-Ob2-3) }\end{array}$ \\
\hline $\begin{array}{l}\text { Female age } \\
\text { (years) }\end{array}$ & $34.7 \pm 4.7$ & $34.7 \pm 4.9$ & $34.1 \pm 5.3$ & $\begin{array}{l}\text { NS } \\
\text { NS }\end{array}$ & $33.8 \pm 5.3$ & $34.6 \pm 5.2$ & $\begin{array}{l}\text { NS } \\
\text { NS }\end{array}$ \\
\hline $\begin{array}{l}\text { Female BMI } \\
\left(\mathrm{kg} / \mathrm{m}^{2}\right)\end{array}$ & $21.6 \pm 1.8$ & $27.2 \pm 1.4$ & $34.3 \pm 3.7$ & & $32.0 \pm 1.5$ & $38.3 \pm 2.9$ & \\
\hline $\begin{array}{c}\text { Female tobacco use } \\
(\%)\end{array}$ & 27.5 & 26.8 & 32.8 & $\begin{array}{l}<0.01 \\
<0.001\end{array}$ & 36.5 & 27.1 & $\begin{array}{c}<0.001 \\
\text { NS }\end{array}$ \\
\hline $\begin{array}{l}\text { Female AMH on } \mathrm{d} 3 \\
(\mathrm{ng} / \mathrm{ml})\end{array}$ & $2.6 \pm 2.4$ & $2.2 \pm 1.8$ & $2.8 \pm 2.4$ & $\begin{array}{l}\text { NS } \\
\text { NS }\end{array}$ & $2.5 \pm 1.8$ & $3.3 \pm 2.7$ & $\begin{array}{l}\text { NS } \\
\text { NS }\end{array}$ \\
\hline $\begin{array}{l}\text { Male BMI } \\
\left(\mathrm{kg} / \mathrm{m}^{2}\right)\end{array}$ & $24.4 \pm 4.9$ & $24.5 \pm 6.9$ & $27.0 \pm 2.2$ & $\begin{array}{c}\text { NS } \\
<0.001\end{array}$ & $26.1 \pm 3.6$ & $30.1 \pm 6.3$ & $\begin{array}{l}<0.001 \\
<0.001\end{array}$ \\
\hline $\begin{array}{c}\text { Male tobacco } \\
(\%)\end{array}$ & 38.0 & 45.8 & 50 & $\begin{array}{l}<0.05 \\
<0.01\end{array}$ & 48.1 & 53.0 & $\begin{array}{c}<0.01 \\
\text { NS }\end{array}$ \\
\hline $\begin{array}{c}\text { Normal } \\
\text { sperm (\%) }\end{array}$ & 57.0 & 49.4 & 58.3 & $\begin{array}{l}\text { NS } \\
\text { NS }\end{array}$ & 59.5 & 56.1 & $\begin{array}{l}\text { NS } \\
\text { NS }\end{array}$ \\
\hline $\begin{array}{c}\text { Primary } \\
\text { infertility (\%) }\end{array}$ & 65.2 & 60.5 & 49.5 & $\begin{aligned} & \mathrm{NS} \\
< & 0.001\end{aligned}$ & 56.2 & 38.0 & $\begin{aligned} & \text { NS } \\
< & 0.001\end{aligned}$ \\
\hline $\begin{array}{c}\text { Indications } \\
(\%) \\
\text { Tubal } \\
\text { Endometriosis } \\
\text { Ovulary dysfunction } \\
\text { Low OvR } \\
\text { Unexplained } \\
\text { Masculine } \\
\text { Mixed } \\
\text { Uterine }\end{array}$ & $\begin{array}{c}16 \\
10 \\
3 \\
15 \\
8 \\
27 \\
19 \\
2\end{array}$ & $\begin{array}{c}20 \\
6 \\
5 \\
7 \\
6 \\
25 \\
30 \\
1\end{array}$ & $\begin{array}{c}18 \\
3 \\
23 \\
4 \\
4 \\
24 \\
23 \\
1\end{array}$ & $\begin{array}{l}<0.05 \\
<0.05\end{array}$ & & & \\
\hline $\begin{array}{c}\text { Cycle rank } \\
\qquad \begin{array}{c}(\%) \\
1 \\
2 \\
3 \\
4 \\
\geq 5\end{array}\end{array}$ & $\begin{array}{c}42.5 \\
26.4 \\
13.3 \\
7.5 \\
10.3\end{array}$ & $\begin{array}{c}39.5 \\
29.1 \\
16.5 \\
8.1 \\
6.8\end{array}$ & $\begin{array}{c}38.5 \\
31.8 \\
16.1 \\
5.7 \\
7.9\end{array}$ & $\begin{array}{l}\text { NS } \\
\text { NS }\end{array}$ & $\begin{array}{c}40.5 \\
32.2 \\
14.9 \\
5.0 \\
7.4\end{array}$ & $\begin{array}{c}35.2 \\
31.0 \\
18.3 \\
7.0 \\
8.5\end{array}$ & $\begin{array}{l}\text { NS } \\
\text { NS }\end{array}$ \\
\hline
\end{tabular}

Legends: NW: normal weight; OW: overweight; Ob: obese; BMI: body mass index; AMH: anti-Müllerian hormone; d3: day 3; OvR: ovarian reserve; NS: not significant 
Table 2. IVF/ICSI cycles and outcomes

\begin{tabular}{|c|c|c|c|c|c|c|c|}
\hline & NW women & OW women & Ob women & $\begin{array}{c}p \\
\text { (NW-OW) } \\
\text { (NW-Ob) }\end{array}$ & Ob1 women & Ob2-3 women & $\begin{array}{c}\text { p } \\
\text { (NW-Ob1) } \\
\text { (NW-Ob2-3) }\end{array}$ \\
\hline Cycles (n) & 652 & 309 & 192 & & 121 & 71 & \\
\hline Protocol GnRH-antagonist (\%) & 81.3 & 84.8 & 86.5 & $\begin{array}{l}\text { NS } \\
\text { NS }\end{array}$ & 87.6 & 84.5 & $\begin{array}{l}\text { NS } \\
\text { NS }\end{array}$ \\
\hline Initial dose of Gnt (IU/d) & $271 \pm 118$ & $275 \pm 122$ & $282 \pm 118$ & $\begin{array}{l}\text { NS } \\
\text { NS }\end{array}$ & $294 \pm 119$ & $263 \pm 117$ & $\begin{array}{l}\text { NS } \\
\text { NS }\end{array}$ \\
\hline Total dose of Gnt (IU) & $2621 \pm 1306$ & $2630 \pm 1286$ & $2928 \pm 1317$ & $\begin{array}{c}\mathrm{NS} \\
<0.01\end{array}$ & $3056 \pm 1304$ & $2706 \pm 1311$ & $\begin{array}{l}<0.001 \\
\text { NS }\end{array}$ \\
\hline Stimulation duration (d) & $9.8 \pm 1.9$ & $9.7 \pm 1.8$ & $10.5 \pm 2.2$ & $\begin{aligned} & \mathrm{NS} \\
< & 0.001\end{aligned}$ & $10.6 \pm 2.2$ & $10.4 \pm 2.2$ & $\begin{array}{l}<0.001 \\
<0.05\end{array}$ \\
\hline Estradiol level jhCG (pg/ml) & $2120 \pm 990$ & $2080 \pm 1189$ & $2231 \pm 1290$ & $\begin{array}{l}\text { NS } \\
\text { NS }\end{array}$ & $2166 \pm 1298$ & $2169 \pm 1321$ & $\begin{array}{l}\text { NS } \\
\text { NS }\end{array}$ \\
\hline Endometrial thickness (mm) & $9.7 \pm 1.9$ & $10.1 \pm 1.7$ & $11.1 \pm 2.4$ & $\begin{array}{l}<0.05 \\
<0.001\end{array}$ & $11.2 \pm 2.6$ & $10.9 \pm 2.3$ & $\begin{array}{l}\text { NS } \\
\text { NS }\end{array}$ \\
\hline Retrievals (n) & 608 & 282 & 177 & & 115 & 62 & \\
\hline $\begin{array}{l}\text { Oocytes retrieved } \\
\text { (medium } \pm \text { range) }\end{array}$ & $9 \pm 5$ & $9 \pm 5$ & $8 \pm 5$ & $\begin{array}{l}\text { NS } \\
\text { NS }\end{array}$ & $8 \pm 4$ & $7 \pm 6$ & $\begin{array}{l}\text { NS } \\
\text { NS }\end{array}$ \\
\hline $\begin{array}{l}\text { Mature oocytes } \\
\text { (medium } \pm \text { range) }\end{array}$ & $7 \pm 4$ & $7 \pm 4$ & $6 \pm 4$ & $\begin{array}{c}\mathrm{NS} \\
<0.05\end{array}$ & $6 \pm 3$ & $6 \pm 5$ & $\begin{array}{l}\text { NS } \\
\text { NS }\end{array}$ \\
\hline ICSI (\%) & 56.7 & 65.7 & 59.4 & $\begin{array}{l}<0.01 \\
\text { NS }\end{array}$ & 61.2 & 56.3 & $\begin{array}{l}\text { NS } \\
\text { NS }\end{array}$ \\
\hline $\begin{array}{c}\text { Embryos obtained } \\
\text { (medium } \pm \text { range) }\end{array}$ & $5 \pm 3$ & $5 \pm 3$ & $4 \pm 3$ & $\begin{array}{c}\text { NS } \\
<0.01\end{array}$ & $5 \pm 3$ & $4 \pm 3$ & $\begin{array}{c}\text { NS } \\
<0.05\end{array}$ \\
\hline Transfers (n) & 379 & 186 & 100 & & 74 & 26 & \\
\hline Embryos transferred (n) & $1.4 \pm 0.5$ & $1.4 \pm 0.5$ & $1.4 \pm 0.4$ & $\begin{array}{l}\text { NS } \\
\text { NS }\end{array}$ & $1.4 \pm 0.5$ & $1.3 \pm 0.4$ & $\begin{array}{l}\text { NS } \\
\text { NS }\end{array}$ \\
\hline Clinical pregnancy $n,(\%)$ & $\begin{array}{c}110 \\
18.1\end{array}$ & $\begin{array}{c}48 \\
17.0\end{array}$ & $\begin{array}{c}36 \\
20.3\end{array}$ & $\begin{array}{l}\text { NS } \\
\text { NS }\end{array}$ & $\begin{array}{c}27 \\
23.5\end{array}$ & $\begin{array}{c}9 \\
14.5\end{array}$ & $\begin{array}{l}\text { NS } \\
\text { NS }\end{array}$ \\
\hline Miscarriage (\%) & 3.8 & 3.2 & 3.4 & $\begin{array}{l}\text { NS } \\
\text { NS }\end{array}$ & 3.5 & 3.2 & $\begin{array}{l}\text { NS } \\
\text { NS }\end{array}$ \\
\hline Live birth n, (\%) & $\begin{array}{c}99 \\
16.3\end{array}$ & $\begin{array}{c}44 \\
15.6\end{array}$ & $\begin{array}{c}31 \\
17.5\end{array}$ & $\begin{array}{l}\text { NS } \\
\text { NS }\end{array}$ & $\begin{array}{c}23 \\
20.0\end{array}$ & $\begin{array}{c}8 \\
12.9\end{array}$ & $\begin{array}{l}\text { NS } \\
\text { NS }\end{array}$ \\
\hline
\end{tabular}

Legends: NW: normal weight; OW: overweight; Ob: obese; Gnt: gonadotrophin; NS: not significant

more frequent $(\mathrm{p}<0.01)$ in the OW group. There were 229 cancellations (37.6\%) between oocyte retrieval and embryo transfer in the NW group, with 96 (34\%) in the OW group and 77 (43.5\%) in the Ob group. There were several reasons for these cancellations: retrieval failure (2.8\%, 3.7\% and $8.5 \%$ in the NW, OW and Ob groups, respectively), poor oocyte quality or fertilization failure $(21.9 \%, 27.7 \%$ and $31.9 \%$, respectively), poor embryo quality $(25.5,31.4$ and $27.6 \%$, respectively) and a few other rare causes. In the NW group, "freeze-all" accounted for $49.7 \%$ of the cancellations, with a mean of $2.8 \pm 2.1$ frozen embryos and $12.2 \%$ of couples lacked an embryo after prolonged culture. These values were $37.5 \%$ in the OW group $(3.5 \pm 2.3$ embryos frozen; $11.1 \%$ of the couples lacked an embryo after prolonged culture) and $32.4 \%$ in the Ob group ( $2.6 \pm 1.7$ embryos frozen; $16.0 \%$ of the couples lacked an embryo after prolonged culture).

There were no differences between the NW group and the four other groups with regard to the $\mathrm{CP}$ and live birth rates per oocyte retrieval. The $\mathrm{CP}$ and live birth rates per transfer were respectively $29 \%$ and $26.1 \%$ in the NW group, $25.8 \%$ and $23.6 \%$ in the OW group, $36 \%$ and $31 \%$ in the OB group, $36.4 \%$ and $31 \%$ in the Ob1 subgroup, and $34.6 \%$ and $30.7 \%$ in the Ob2 subgroup. These differences were not significant. The miscarriage rates in the three groups were similar.

The mean number of embryos transferred was the same in all three groups. The NW, OW and $\mathrm{Ob}$ groups did not differ with regard to the numbers of single-embryo and two-embryo transfers, the number of blastocysts transferred (mean: 1.33) or the proportion of cleaved embryos (D2 or D3), even though the CP rates were higher (although not significantly) after blastocyst transfer than after embryo transfer (NW: $32.5 \%$ vs. $24.3 \%$ per transfer, respectively; OW: $29.7 \%$ vs. $20 \%$ per transfer; Ob: $39.2 \%$ vs. $31.8 \%$ per transfer).

In a univariate analysis (Table 3 ) of the IVF/ICSI cycles, certain factors were positively associated with $\mathrm{CP}$ in the three weight groups. A few factors were common to both $\mathrm{OW}$ and $\mathrm{Ob}$ women: male tobacco use, male infertility, unexplained infertility, and $\geq 5$ embryos obtained. Other factors were negatively associated with $\mathrm{CP}$ in the three weight groups. Only the "mixed" infertility indication (i.e. both male and female infertility) was common to the OW and Ob groups. In a multivariate analysis (Table 4 ), female tobacco use and $\geq 5$ embryos obtained had a positive effect on the $\mathrm{CP}$ rate in $\mathrm{OW}$ and $\mathrm{Ob}$ women under the age of 34 . In obese women, primary infertility also had a positive effect on the $\mathrm{CP}$ rate.

We also studied a total of 541 IUI cycles in women of normal weight $(n=350)$, overweight women $(n=100)$ and obese women $(n=91)$. The women's demographic data are summarized in Table 5. The obese women (particularly those in the Ob1 subgroup) were younger and had a higher AMH level. The IUI cycles are described in Table 6. The initial dose of gonadotrophins, the total gonadotrophin dose, and the duration of stimulation were significantly greater in the $\mathrm{Ob}$ group than in the two other groups - mainly because of the Ob2 subgroup. However, the plasma estradiol level on the hCG day was significantly lower in the $\mathrm{Ob}$ group than in the two other groups. Certain women did not undergo IUI (due to more than 3 follicles responding to stimulation, or a plasma progesterone level $\geq 1.5 \mathrm{ng} / \mathrm{ml}$ ): this criterion concerned $8.2 \%$ of the 
Merviel P (2020) Effects of female body mass index on the outcome of in vitro fertilization/intracytoplasmic sperm injection or intrauterine insemination

Table 3. IVF/ICSI : univariate analysis

\begin{tabular}{|c|c|c|c|c|c|}
\hline \multirow[t]{2}{*}{ Variables } & Normal weight (NW) & Overweight (OW & \multirow{2}{*}{$\begin{array}{c}p \\
{[\mathrm{NW}-\mathrm{OW}]} \\
\text { adjusted }\end{array}$} & \multirow{2}{*}{$\begin{array}{c}\text { Obese (Ob) } \\
\text { OR }(95 \% \mathrm{CI}) \\
\text { unadjusted }\end{array}$} & \multirow{2}{*}{$\begin{array}{c}\text { p } \\
\text { [NW-Ob] } \\
\text { adjusted }\end{array}$} \\
\hline & $\begin{array}{c}\text { OR }(95 \% \mathrm{CI}) \\
\text { unadjusted }\end{array}$ & $\begin{array}{c}\text { OR }(95 \% \mathrm{CI}) \\
\text { unadjusted }\end{array}$ & & & \\
\hline \multicolumn{6}{|l|}{$\begin{array}{l}\text { Clinical pregnancy rate (CPR): positive } \\
\text { impact/variable for each group }\end{array}$} \\
\hline Female age $<34$ y.o & $0.98[0.74-1.22]$ & $1.20[0.96-1.44]$ & $<0.05^{b}$ & $1.37[1.13-1.61]$ & $<0.05^{\mathrm{c}}$ \\
\hline Female tobacco & $0.96[0.77-1.15]$ & $1.27[1.06-1.48]$ & $<0.05^{\text {b }}$ & $1.05[0.84-1.26]$ & NS \\
\hline Male tobacco & $1.22[0.99-1.55]$ & $1.30[1.06-1.54]$ & NS & $3.25[3.00-3.50]$ & $<0.05^{\mathrm{c}}$ \\
\hline Male NW & $1.04[0.80-1.28]$ & $1.26[1.03-1.49]$ & NS & $1.12[0.93-1.31]$ & NS \\
\hline Primary infertility & $0.91[0.69-1.13]$ & $1.02[0.78-1.26]$ & NS & $1.31[1.06-1.56]$ & $<0.05^{\mathrm{c}}$ \\
\hline $\begin{array}{c}\text { Indications } \\
\text { Ovulatory (+ PCOS) } \\
\text { PCOS } \\
\text { Low OvR } \\
\text { Unexplained } \\
\text { Masculine }\end{array}$ & $\begin{array}{l}1.38[1.31-1.45] \\
1.10[0.91-1.29]\end{array}$ & $\begin{array}{l}2.10[2.06-2.14] \\
1.87[1.81-1.93] \\
1.67[1.63-1.71] \\
1.25[1.20-1.30]\end{array}$ & $\begin{array}{l}<0.05^{\text {b }} \\
<0.05^{\text {b }} \\
<0.05^{\text {b }} \\
<0.05^{\text {b }}\end{array}$ & $\begin{array}{l}1.64[1.61-1.67] \\
2.46[2.41-2.49] \\
1.64[1.46-1.82]\end{array}$ & $\begin{array}{l}<0.05^{\mathrm{c}} \\
<0.05^{\mathrm{c}} \\
<0.05^{\mathrm{c}}\end{array}$ \\
\hline Endometrial thickness $\geq 9 \mathrm{~mm}$ & $0.92[0.68-1.16]$ & $1.15[0.94-1.36]$ & NS & $1.23[1.07-1.39]$ & $<0.05^{\mathrm{c}}$ \\
\hline ICSI use & $1.04[0.80-1.28]$ & $1.05[0.83-1.27]$ & NS & $1.39[1.15-1.63]$ & $<0.05^{\mathrm{c}}$ \\
\hline Embryos obtained $\geq 5$ & $1.11[0.87-1.35]$ & $1.31[1.07-1.55]$ & NS & $1.28[1.04-1.52]$ & $<0.05^{\mathrm{c}}$ \\
\hline \multicolumn{6}{|c|}{$\begin{array}{l}\text { Clinical pregnancy rate }(\mathrm{CPR}) \text { : negative } \\
\text { impact/variable in each group }\end{array}$} \\
\hline Male $\mathrm{Ob}$ & $1.22[1.03-1.41]$ & $0.56[0.47-0.65]$ & $<0.05^{\text {a }}$ & $0.91[0.79-1.03]$ & $<0.05^{\text {a }}$ \\
\hline $\begin{array}{c}\text { Indications } \\
\text { Tubal } \\
\text { Endometriosis } \\
\text { Ovulatory }(+ \text { PCOS }) \\
\text { PCOS } \\
\text { Low OvR } \\
\text { Mixed }\end{array}$ & $\begin{array}{l}0.95[0.83-1.07] \\
1.24[1.23-1.25] \\
0.52[0.49-0.55] \\
0.84[0.81-0.87] \\
0.58[0.46-0.70] \\
0.97[0.82-1.12]\end{array}$ & $\begin{array}{l}1.12[0.97-1.27] \\
0.36[0.35-0.37]\end{array}$ & $\begin{array}{c}\mathrm{NS} \\
<0.05^{\text {a }} \\
\\
\mathrm{NS} \\
<0.05^{\text {a }}\end{array}$ & $\begin{array}{c}0.81[0.67-0.95] \\
- \\
0.50[0.33-0.67] \\
0.71[0.55-0.87] \\
\\
0.77[0.60-0.94]\end{array}$ & 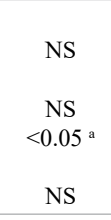 \\
\hline Estradiol level $\geq 2,000 \mathrm{pg} / \mathrm{ml}$ & $1.03[0.78-1.28]$ & $0.61[0.37-0.85]$ & $<0.05^{\text {a }}$ & $0.81[0.57-1.05]$ & NS \\
\hline
\end{tabular}

Legends: $p$ adjusted to the reference (NW women): ${ }^{a}$ : $p$ to the benefit of NW; ${ }^{\text {b }}$ p to the benefit of OW and ${ }^{c}$ : $p$ to the benefit of Ob; PCOS: polycycstic ovary syndrome; OvR: ovarian reserve

OR not significant (NS): Male overweight (female NW, OW and Ob); Cycle rank $\leq 2$ (NW, OW, and Ob); GnRH antagonist use (NW, OW, and Ob); FSH use (NW, OW, and Ob); Total dose of gonadotrophins $\leq 2500 \mathrm{IU}$ (NW, OW, Ob); progesterone level $\leq 1 \mathrm{ng} / \mathrm{ml}$ ( $\mathrm{OW}$ and $\mathrm{Ob}$ ); Oocytes $\geq 9$ (NW, OW, and Ob); Embryos transferred $>1$ (NW, OW, and Ob); Blastocyst transfer (NW, OW, Ob)

Table 4. IVF/ICSI : multivariate analysis

\begin{tabular}{|c|c|c|c|}
\hline Variables and BMI categories & (\% cases) & $\begin{array}{c}\text { Multivariate analysis } \\
\text { OR }[95 \% \mathrm{CI}]\end{array}$ & $\mathbf{p}$ \\
\hline $\begin{array}{c}\text { Female age }<34 \text { y.o } \\
\text { NW } \\
\text { OW } \\
\text { Obese }\end{array}$ & $\begin{array}{l}40.0 \\
45.0 \\
48.5\end{array}$ & $\begin{array}{l}1.00 \text { (reference) } \\
1.42[1.15-1.69] \\
1.70[1.41-1.79]\end{array}$ & $\begin{array}{l}<0.001 \\
<0.001\end{array}$ \\
\hline $\begin{array}{c}\text { Female tobacco use } \\
\text { NW } \\
\text { OW } \\
\text { Obese }\end{array}$ & $\begin{array}{l}28.1 \\
26.2 \\
44.6\end{array}$ & $\begin{array}{l}1.00 \text { (reference) } \\
1.53[1.28-1.78] \\
1.33[1.07-1.59]\end{array}$ & $\begin{array}{l}<0.001 \\
<0.001\end{array}$ \\
\hline $\begin{array}{c}\text { Primary infertility } \\
\text { NW } \\
\text { OW } \\
\text { Obese }\end{array}$ & $\begin{array}{l}64.4 \\
60.6 \\
50.8\end{array}$ & $\begin{array}{l}1.00 \text { (reference) } \\
1.30[0.99-1.61] \\
1.75[1.42-2.08]\end{array}$ & $\begin{aligned} & N S \\
< & 0.001\end{aligned}$ \\
\hline $\begin{array}{c}\text { Oocytes } \geq 9 \\
\text { NW } \\
\text { OW } \\
\text { Obese }\end{array}$ & $\begin{array}{l}41.6 \\
57.8 \\
38.4\end{array}$ & $\begin{array}{l}1.00 \text { (reference) } \\
1.05[0.78-1.32] \\
1.19[0.92-1.46]\end{array}$ & $\begin{array}{l}\text { NS } \\
\text { NS }\end{array}$ \\
\hline $\begin{array}{c}\text { Embryos } \geq 5 \\
\text { NW } \\
\text { OW } \\
\text { Obese }\end{array}$ & $\begin{array}{l}55.2 \\
48.9 \\
49.7\end{array}$ & $\begin{array}{l}1.00 \text { (reference) } \\
1.36[1.11-1.61] \\
1.40[1.14-1.66]\end{array}$ & $\begin{array}{l}<0.001 \\
<0.001\end{array}$ \\
\hline
\end{tabular}

Legends: NW: normal weight; OW: overweight; Ob: obese; BMI: body mass index; AMH: anti-Müllerian hormone; d3: day 3; OvR: ovarian reserve; NS: not significant 
Table 5. Demographic data for the IUI population

\begin{tabular}{|c|c|c|c|c|c|c|c|}
\hline & NW women & OW women & Ob women & $\begin{array}{c}p \\
\text { (NW-OW) } \\
(\mathrm{NW}-\mathrm{Ob})\end{array}$ & Ob1 women & Ob2-3 women & $\begin{array}{c}p \\
\text { (NW-Ob1) } \\
(\mathrm{NW}-\mathrm{Ob2}-3)\end{array}$ \\
\hline $\begin{array}{l}\text { Female age } \\
\text { (years) }\end{array}$ & $33.3 \pm 4.4$ & $32.8 \pm 5.4$ & $31.7 \pm 5.1$ & $\begin{array}{c}\mathrm{NS} \\
<0.01\end{array}$ & $31.2 \pm 5.1$ & $32.3 \pm 5.0$ & $\begin{array}{l}<0.01 \\
\text { NS }\end{array}$ \\
\hline $\begin{array}{c}\text { Female BMI } \\
\left(\mathrm{kg} / \mathrm{m}^{2}\right)\end{array}$ & $21.9 \pm 1.6$ & $27.2 \pm 1.3$ & $35.3 \pm 3.6$ & & $32.8 \pm 1.7$ & $38.2 \pm 2.9$ & \\
\hline $\begin{array}{l}\text { Female tobacco use } \\
(\%)\end{array}$ & 26.0 & 29.0 & 19.5 & $\begin{array}{l}\text { NS } \\
\text { NS }\end{array}$ & 24.4 & 14.3 & $\begin{array}{l}<0.05 \\
<0.05\end{array}$ \\
\hline Female AMH on d3 (ng/ml) & $2.9 \pm 2.6$ & $2.5 \pm 2.2$ & $4.0 \pm 3.3$ & $\begin{array}{c}\mathrm{NS} \\
<0.05\end{array}$ & $4.4 \pm 3.9$ & $3.2 \pm 1.6$ & $\begin{array}{l}<0.01 \\
\text { NS }\end{array}$ \\
\hline $\begin{array}{l}\text { Male BMI } \\
\left(\mathrm{kg} / \mathrm{m}^{2}\right)\end{array}$ & $24.6 \pm 5.6$ & $27.6 \pm 7.2$ & $25.1 \pm 6.3$ & $\begin{array}{c}<0.001 \\
\text { NS }\end{array}$ & $23.6 \pm 4.3$ & $27.0 \pm 7.7$ & $\begin{array}{c}\mathrm{NS} \\
<0.05\end{array}$ \\
\hline $\begin{array}{l}\text { Male tobacco } \\
(\%)\end{array}$ & 33.9 & 44.2 & 46.2 & $\begin{array}{l}\text { NS } \\
\text { NS }\end{array}$ & 47.6 & 44.4 & $\begin{array}{l}\text { NS } \\
\text { NS }\end{array}$ \\
\hline $\begin{array}{c}\text { Normal } \\
\text { sperm (\%) }\end{array}$ & 69.2 & 52.4 & 72.9 & $\begin{array}{c}<0.01 \\
\mathrm{NS}\end{array}$ & 62.9 & 82.9 & $\begin{array}{l}\text { NS } \\
\text { NS }\end{array}$ \\
\hline $\begin{array}{c}\text { Primary } \\
\text { infertility }(\%)\end{array}$ & 55.7 & 49.5 & 42.9 & $\begin{array}{l}\text { NS } \\
\text { NS }\end{array}$ & 51.0 & 33.3 & $\begin{array}{l}\text { NS } \\
\text { NS }\end{array}$ \\
\hline $\begin{array}{c}\text { Indications } \\
(\%) \\
\text { Tubal } \\
\text { Endometriosis } \\
\text { Ovulary dysfunction } \\
\text { Low OvR } \\
\text { Unexplained } \\
\text { Masculine } \\
\text { Mixed } \\
\text { Cervical } \\
\text { Uterine }\end{array}$ & $\begin{array}{c}0 \\
5 \\
12 \\
20 \\
16 \\
34 \\
4 \\
6 \\
3\end{array}$ & $\begin{array}{c}1 \\
3 \\
12 \\
16 \\
23 \\
39 \\
5 \\
1 \\
0\end{array}$ & $\begin{array}{c}4 \\
2 \\
26 \\
6 \\
15 \\
34 \\
10 \\
3 \\
0\end{array}$ & $\begin{array}{l}<0.05 \\
<0.05\end{array}$ & & & \\
\hline 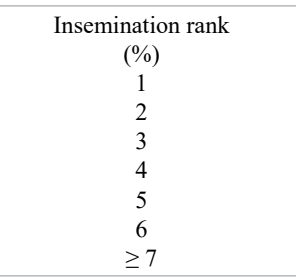 & $\begin{array}{c}34.0 \\
46.6 \\
8.9 \\
6.0 \\
2.6 \\
2.0 \\
0\end{array}$ & $\begin{array}{c}43.0 \\
46.0 \\
6.0 \\
4.0 \\
0 \\
1.0 \\
0\end{array}$ & $\begin{array}{c}42.9 \\
48.4 \\
4.4 \\
2.2 \\
1.1 \\
0 \\
1.1\end{array}$ & $\begin{array}{l}\text { NS } \\
\text { NS }\end{array}$ & $\begin{array}{c}46.9 \\
46.9 \\
4.1 \\
0 \\
0 \\
0 \\
2.0\end{array}$ & $\begin{array}{c}38.1 \\
50.0 \\
4.8 \\
4.8 \\
2.4 \\
0 \\
0\end{array}$ & $\begin{array}{l}\text { NS } \\
\text { NS }\end{array}$ \\
\hline
\end{tabular}

Legends: NW: normal weight; OW: overweight; Ob: obese; BMI: body mass index; AMH: anti-Müllerian hormone; d3: day 3; OvR: ovarian reserve; NS: not significant

women in the NW group, $7 \%$ in the OW group, and $13.1 \%$ in the $\mathrm{Ob}$ group. The number of inseminated spermatozoids was lower in the OW group, due to a significantly higher male BMI and significantly lower sperm quality (Table 6). The CP and live birth rates were significantly higher in Ob group than in the NW and OW groups. The difference between the NW and OW groups was not significant. The miscarriage rates in the three groups were similar.

In a univariate analysis (Table 7) of the IUI results, certain factors appeared to be beneficial for the women - regardless of weight. Only an estradiol level $\geq 300 \mathrm{pg} / \mathrm{ml}$ on the trigger day was found in both the $\mathrm{OW}$ and $\mathrm{Ob}$ groups. Other factors were negative in the weight groups. Male tobacco use, male overweight, male obesity, unexplained infertility, a serum progesterone level $\leq 1 \mathrm{ng} / \mathrm{ml}$ on the trigger day, and a monofollicular response to ovarian stimulation were found in both the OW and Ob groups. In a multivariate analysis (Table 8), female tobacco use, primary infertility, and a monofollicular response to ovarian stimulation were negative predictive factors for $\mathrm{CP}$ in the $\mathrm{OW}$ and $\mathrm{Ob}$ groups. In the OW group, a sperm count $\geq 5$ million on the day of insemination was a negative predictive factor.

\section{Discussion}

In the present study, we did not find any impact of female overweight or obesity on the $\mathrm{CP}$ and live birth rates per oocyte retrieval.
The literature data are contradictory. In 2003, Steinkampf et al. [18] reported a decrease in the likelihood of pregnancy for overweight women in IVF (OR: 0.53; 95\%CI [0.32-0.86]). Two major studies (performed in the USA by the SART in 2007 (45,163 cycles, [19]) and in Germany $(650,452$ cycles, [20])) found that the pregnancy rate fell with rising female weight (albeit only in women under 35, in the American study). Similarly, Zander-Fox et al.'s study [21] found that a BMI > 40 had an impact on the CP rate in women under 38 (30.5\%, versus $41.1 \%$ in women with a BMI $\leq 40 ; \mathrm{p}<0.05)$. Sneed et al. [22] reported that the impact of BMI on the likelihood of pregnancy decreased after the age of 36 , which contrasts with our present observations (i.e. female age $\leq 34$ was a significantly positive factor in obese women). It is probable that after the age of 36 , other factors have a greater influence than BMI on the relative decrease in the likelihood of pregnancy; this would explain our results and those reported by Sneed et al. [22] and Zander-Fox et al. [21]. Provost et al. [23] compared the live birth rates for 239,127 IVF cycles as a function of the BMI. The difference was significant, with a negative, direct correlation between the live birth rate and the BMI $(31.4 \%$ per cycle in women with a normal BMI vs. $28 \%$ in women with a BMI of between 30 and $34.9 \mathrm{~kg} / \mathrm{m}^{2}$ (OR: 0.84 ; 95\%CI [0.81-0.87]; $\mathrm{p}<0.001)$, and $21.2 \%$ in women with a BMI over $50 \mathrm{~kg} / \mathrm{m}^{2}$ (OR: 0.52; 95\%CI [0.41-0.66]; $\mathrm{p}<0.001$ ). The mean age in Provost et al.'s study was 35 , which is similar to the mean age in our study. The mean number of embryos transferred was 2.4 for all the BMI 
Merviel P (2020) Effects of female body mass index on the outcome of in vitro fertilization/intracytoplasmic sperm injection or intrauterine insemination

Table 6. IUI cycles and outcomes

\begin{tabular}{|c|c|c|c|c|c|c|c|}
\hline & NW women & OW women & Ob women & $\begin{array}{c}\mathrm{p} \\
(\mathrm{NW}-\mathrm{OW}) \\
(\mathrm{NW}-\mathrm{Ob})\end{array}$ & Ob1 women & Ob2-3 women & $\begin{array}{c}\mathrm{p} \\
\text { (NW-Ob1) } \\
\text { (NW-Ob2-3) }\end{array}$ \\
\hline Cycles (n) & 350 & 100 & 91 & & 49 & 42 & \\
\hline $\begin{array}{c}\text { Protocol } \\
(\%) \\
\text { Clomiphene } \\
\text { FSH/hMG } \\
\text { Natural }\end{array}$ & $\begin{array}{c}0 \\
99.4 \\
0.6\end{array}$ & $\begin{array}{c}0 \\
100 \\
0\end{array}$ & $\begin{array}{c}9.9 \\
90.1 \\
0\end{array}$ & $\begin{aligned} & \text { NS } \\
< & 0.001\end{aligned}$ & $\begin{array}{c}10.2 \\
89.8 \\
0\end{array}$ & $\begin{array}{c}9.5 \\
90.5 \\
0\end{array}$ & $\begin{array}{l}<0.001 \\
<0.001\end{array}$ \\
\hline $\begin{array}{l}\text { Initial dose of } \\
\text { Gnt (IU/d) }\end{array}$ & $62 \pm 26$ & $62 \pm 27$ & $71 \pm 28$ & $\begin{array}{l}\mathrm{NS} \\
<0.01\end{array}$ & $69 \pm 30$ & $74 \pm 25$ & $\begin{array}{l}\mathrm{NS} \\
<0.01\end{array}$ \\
\hline $\begin{array}{l}\text { Total dose of } \\
\text { Gnt (IU) }\end{array}$ & $606 \pm 396$ & $614 \pm 389$ & $928 \pm 751$ & $\begin{aligned} & \mathrm{NS} \\
< & 0.001\end{aligned}$ & $738 \pm 544$ & $1149 \pm 886$ & $\begin{aligned} & \mathrm{NS} \\
< & 0.001\end{aligned}$ \\
\hline Stimulation duration (d) & $9.5 \pm 3.1$ & $9.6 \pm 3.8$ & $10.9 \pm 3.9$ & $\begin{array}{l}\text { NS } \\
<0.01\end{array}$ & $10.2 \pm 3.6$ & $11.7 \pm 4.2$ & $\begin{aligned} & \text { NS } \\
< & 0.001\end{aligned}$ \\
\hline $\begin{array}{l}\text { Monofollicular } \\
\text { Response (\%) }\end{array}$ & 55.1 & 54.8 & 64.8 & $\begin{array}{l}\text { NS } \\
\text { NS }\end{array}$ & 67.4 & 61.0 & $\begin{array}{l}\text { NS } \\
\text { NS }\end{array}$ \\
\hline $\begin{array}{l}\text { Estradiol level } \\
\text { jhCG (pg/ml) }\end{array}$ & $383 \pm 193$ & $326 \pm 204$ & $264 \pm 107$ & $\begin{aligned} & \mathrm{NS} \\
< & 0.001\end{aligned}$ & $262 \pm 78$ & $269 \pm 144$ & $\begin{array}{l}<0.01 \\
<0.05\end{array}$ \\
\hline $\begin{array}{c}\text { Endometrial } \\
\text { thickness (mm) }\end{array}$ & $9.0 \pm 2.2$ & $9.9 \pm 2.3$ & $8.7 \pm 1.6$ & $\begin{array}{l}<0.05 \\
\text { NS }\end{array}$ & $8.9 \pm 1.6$ & $8.4 \pm 1.5$ & $\begin{array}{l}\text { NS } \\
\text { NS }\end{array}$ \\
\hline IUI (n) & 321 & 93 & 79 & & 43 & 36 & \\
\hline $\begin{array}{c}\text { Inseminated } \\
\text { Spermatozoa (million) }\end{array}$ & $9.0 \pm 4.9$ & $6.7 \pm 5.3$ & $9.4 \pm 5.1$ & $\begin{array}{l}<0.01 \\
\mathrm{NS}\end{array}$ & $7.1 \pm 5.1$ & $12.5 \pm 3.2$ & $\begin{array}{l}\mathrm{NS} \\
<0.01\end{array}$ \\
\hline $\begin{array}{l}\text { Clinical pregnancy }(\mathrm{n}) \\
\text { (/insemination\%) }\end{array}$ & $\begin{array}{ll}39 & \\
& 12.2\end{array}$ & $\begin{array}{ll}18 \\
& \\
& \end{array}$ & $\begin{array}{l}17 \\
21.6\end{array}$ & $\begin{array}{c}\mathrm{NS} \\
<0.05\end{array}$ & ${ }^{10} 23.2$ & $\begin{array}{ll}7 & \\
& 19.4\end{array}$ & $\begin{array}{l}<0.05 \\
\text { NS }\end{array}$ \\
\hline Miscarriage (\%) & 2.5 & 4.3 & 3.8 & $\begin{array}{l}\text { NS } \\
\text { NS }\end{array}$ & 7.0 & 0 & $\begin{array}{l}\text { NS } \\
\text { NS }\end{array}$ \\
\hline $\begin{array}{c}\text { Live birth (n) } \\
\text { (/insemination\%) }\end{array}$ & $\begin{array}{l}30 \\
9.3\end{array}$ & $\begin{array}{c}12 \\
12.9\end{array}$ & $\begin{array}{c}14 \\
17.7\end{array}$ & $\begin{array}{c}\mathrm{NS} \\
<0.05\end{array}$ & $\begin{array}{c}8 \\
18.6\end{array}$ & $\begin{array}{c}6 \\
16.7\end{array}$ & $\begin{array}{l}\text { NS } \\
\text { NS }\end{array}$ \\
\hline
\end{tabular}

Legends: NW: normal weight; OW: overweight; Ob: obese; Gnt: gonadotrophin; NS: not significant

Table 7. IUI : univariate analysis

\begin{tabular}{|c|c|c|c|c|c|}
\hline Variables & Normal weight (NW) & Overweight (OW & & Obese (Ob) & \\
\hline & $\begin{array}{l}\text { OR }(95 \% \mathrm{CI}) \\
\text { unadjusted }\end{array}$ & $\begin{array}{l}\text { OR }(95 \% \mathrm{CI}) \\
\text { unadjusted }\end{array}$ & $\begin{array}{l}\mathrm{p}[\mathrm{NW}-\mathrm{OW}] \\
\text { adjusted }\end{array}$ & $\begin{array}{l}\text { OR }(95 \% \mathrm{CI}) \\
\text { unadjusted }\end{array}$ & $\begin{array}{l}\mathrm{p}[\mathrm{NW}-\mathrm{Ob}] \\
\text { adjusted }\end{array}$ \\
\hline \multicolumn{6}{|l|}{$\begin{array}{l}\text { Clinical pregnancy rate }(\mathrm{CPR}) \text { : positive } \\
\text { impact/variable for each group }\end{array}$} \\
\hline $\begin{array}{c}\text { Indications } \\
\text { Ovulatory }(+ \text { PCOS }) \\
\text { PCOS }\end{array}$ & $\begin{array}{l}1.88[1.78-1.88] \\
1.02[0.98-1.06]\end{array}$ & $\begin{array}{l}1.40[1.31-1.49] \\
1.46[1.39-1.53]\end{array}$ & $\begin{array}{l}<0.05^{\text {b }} \\
<0.05^{\text {b }}\end{array}$ & $1.00[0.81-1.19]$ & NS \\
\hline Estradiol level $\geq 300 \mathrm{pg} / \mathrm{ml}$ & $1.28[1.04-1.52]$ & $1.42[1.19-1.65]$ & $<0.05^{\text {b }}$ & $1.25[1.06-1.44]$ & $<0.05^{\mathrm{c}}$ \\
\hline $\begin{array}{l}\text { Inseminated sperm } \\
\quad \geq 5 \text { million }\end{array}$ & $1.44[1.24-1.64]$ & $1.07[0.83-1.31]$ & NS & $1.54[1.35-1.73]$ & $<0.05^{\mathrm{c}}$ \\
\hline \multicolumn{6}{|c|}{$\begin{array}{l}\text { Clinical pregnancy rate (CPR): negative } \\
\text { impact/variable in each group }\end{array}$} \\
\hline Female tobacco & $1.09[0.90-1.28]$ & $1.06[0.86-1.26]$ & $<0.05^{\mathrm{b}}$ & $0.54[0.39-0.69]$ & NS \\
\hline Male tobacco & $1.10[0.88-1.32]$ & $0.67(0.43-0.91]$ & NS & $0.38[0.14-0.62]$ & $<0.05^{\text {a }}$ \\
\hline Primary infertility & $1.04[0.80-1.28]$ & $0.73[0.49-0.97]$ & NS & $0.82[0.58-1.06]$ & NS \\
\hline $\begin{array}{l}\text { Male } \\
\mathrm{NW} \\
\mathrm{Ob}\end{array}$ & $\begin{array}{l}0.77[0.53-1.01] \\
1.44[1.35-1.53]\end{array}$ & $\begin{array}{l}0.76[0.73-0.79] \\
0.51[0.33-0.69]\end{array}$ & $\begin{array}{l}<0.05^{\text {b }} \\
<0.05^{\text {a }}\end{array}$ & $\begin{array}{l}0.46[0.22-0.70] \\
0.30[0.14-0.46]\end{array}$ & $\begin{array}{l}\text { NS } \\
<0.05^{\text {a }}\end{array}$ \\
\hline $\begin{array}{l}\text { Indications } \\
\text { PCOS } \\
\text { Unexplained } \\
\text { Mixed }\end{array}$ & $\begin{array}{l}0.45[0.32-0.58] \\
0.63[0.40-0.86]\end{array}$ & $\begin{array}{c}0.73[0.56-0.90] \\
-\end{array}$ & $<0.05^{b}$ & $\begin{array}{l}0.74[0.53-0.95] \\
0.35[0.23-0.47] \\
0.51[0.42-0.60]\end{array}$ & $\begin{array}{c}\mathrm{NS} \\
\mathrm{NS} \\
<0.05^{\mathrm{c}}\end{array}$ \\
\hline Insemination rank $\leq 2$ & $0.86[0.70-1.02]$ & $0.98[0.89-1.07]$ & $<0.05^{\text {b }}$ & $0.82[0.75-0.89]$ & $<0.05^{\mathrm{c}}$ \\
\hline FSH use & $0.99[0.82-1.16]$ & $0.95[0.80-1.10]$ & $<0.05^{\text {b }}$ & $0.81[0.74-0.88]$ & $<0.05^{\mathrm{c}}$ \\
\hline Total dose of Gnt $\geq 500 \mathrm{IU}$ & $0.85[0.61-1.09]$ & $0.72[0.47-0.97]$ & NS & $0.85[0.67-1.03]$ & $<0.05^{\mathrm{c}}$ \\
\hline Progesterone level $\leq 1 \mathrm{ng} / \mathrm{ml}$ & $1.25[1.11-1.39]$ & $0.73[0.62-0.84]$ & NS & $0.72[0.62-0.82]$ & NS \\
\hline Monofollicular response & $1.05[0.88-1.22]$ & $0.58[0.41-0.75]$ & NS & $0.81[0.67-0.95]$ & $<0.05^{\mathrm{c}}$ \\
\hline Endometrial thickness $\geq 9 \mathrm{~mm}$ & $1.12[0.91-1.33]$ & $1.14[0.93-1.35]$ & $<0.05^{b}$ & $0.65[0.41-0.89]$ & NS \\
\hline
\end{tabular}

Legends: $p$ adjusted to the reference (NW women): ${ }^{a}$ : $p$ to the benefit of $\mathrm{NW}$; ${ }^{\mathrm{b}}$ : $\mathrm{p}$ to the benefit of $\mathrm{OW}$ and $^{\mathrm{c}}$ : $\mathrm{p}$ to the benefit of Ob; PCOS: polycycstic ovary syndrome; OvR: ovarian reserve; Gnt: gonadotrophin

OR not significant (NS): Female age $<34$ (NW, OW and Ob), Male overweight (female NW, OW and Ob), masculine indication (OW, Ob) 
Table 8. IUI : multivariate analysis

\begin{tabular}{|c|c|c|c|}
\hline Variables and BMI categories & ( $\%$ cases) & $\begin{array}{c}\text { Multivariate analysis } \\
\text { OR }[95 \% \mathrm{CI}]\end{array}$ & $\mathbf{p}$ \\
\hline $\begin{array}{c}\text { Female age }<34 \text { y.o } \\
\text { NW } \\
\text { OW } \\
\text { Obese }\end{array}$ & $\begin{array}{l}53.0 \\
55.0 \\
67.2\end{array}$ & $\begin{array}{l}1.00 \text { (reference) } \\
1.05[0.83-1.27] \\
0.89[0.66-1.12]\end{array}$ & $\begin{array}{l}\text { NS } \\
\text { NS }\end{array}$ \\
\hline $\begin{array}{c}\text { Female tobacco use } \\
\text { NW } \\
\text { OW } \\
\text { Obese }\end{array}$ & $\begin{array}{l}25.2 \\
29.4 \\
18.7\end{array}$ & $\begin{array}{l}1.00 \text { (reference) } \\
0.74[0.60-0.88] \\
0.43[0.31-0.55]\end{array}$ & $\begin{array}{l}<0.001 \\
<0.001\end{array}$ \\
\hline $\begin{array}{c}\text { Primary infertility } \\
\text { NW } \\
\text { OW } \\
\text { Obese }\end{array}$ & $\begin{array}{l}55.5 \\
49.4 \\
42.7\end{array}$ & $\begin{array}{l}1.00 \text { (reference) } \\
0.54[0.37-0.71] \\
0.69[0.49-0.89]\end{array}$ & $\begin{array}{l}<0.001 \\
<0.001\end{array}$ \\
\hline $\begin{array}{c}\text { Monofollicular response } \\
\text { NW } \\
\text { OW } \\
\text { Obese }\end{array}$ & $\begin{array}{l}77.3 \\
77.5 \\
83.6\end{array}$ & $\begin{array}{l}1.00 \text { (reference) } \\
0.42[0.30-0.54] \\
0.67[0.56-0.78]\end{array}$ & $\begin{array}{l}<0.001 \\
<0.001\end{array}$ \\
\hline $\begin{array}{c}\text { Inseminated sperm } \geq 5 \text { million } \\
\text { NW } \\
\text { OW } \\
\text { Obese }\end{array}$ & $\begin{array}{l}71.1 \\
47.8 \\
73.4\end{array}$ & $\begin{array}{l}1.00 \text { (reference) } \\
0.57[0.45-0.69] \\
0.94[0.83-1.05]\end{array}$ & $\begin{array}{l}<0.001 \\
\text { NS }\end{array}$ \\
\hline
\end{tabular}

Legends: BMI: body mass index; OR: odds-ratio; CI: confidence interval; NW: normal weight; OW: overweight; NS: not significant

Clinical pregnancy rate per insemination (NW women): female age $<34: 10.1 \%$; female tobacco use: $13.4 \%$; primary infertility: $12.8 \%$; monofollicular response: $12.9 \%$; inseminated sperm $\geq 5$ million: $17.6 \%$

groups, which might explain why Provost et al. observed higher birth rates (without reporting on multiple pregnancy rates) than we did in the present study. Our policy of promoting single-embryo transfers has resulted in a multiple pregnancy rate of below 15\%. Our results do not support the policy of transferring two embryos with a view to increasing the likelihood of pregnancy; only a monofollicular response to ovarian stimulation in IUI showed a harmful effect in overweight or obese women. In 2008, van der Steeg et al. [24] estimated that the pregnancy rate fell by $5 \%$ for a one-unit increment in BMI beyond 29 $\mathrm{kg} / \mathrm{m}^{2}$. Four major meta-analyses of this topic have been published. In Maheswari et al.'s analysis [25] of 21 studies, women with a BMI $\geq$ 25 were less likely to become pregnant (OR: $0.71 ; 95 \%$ CI [0.62-0.81]) and were more likely to have a miscarriage (OR: 1.33 ; 95\%CI [1.061.68]). In 2011, Rittenberg et al. [26] performed a meta-analysis on 33 studies $(47,967$ cycles $)$ and found that a BMI $\geq 25$ was associated with a significantly lower CP rate (RR: $0.9 ; \mathrm{p}<0.0001)$, birth rate (RR: $0.84 ; \mathrm{p}=0.0002)$, but a significantly higher miscarriage rate (RR: 1.31 ; $\mathrm{p}<0.0001)$. These results were also found in overweight women (BMI: 25-30). In Rittenberg et al.'s series, there was no difference with regard to the number of oocytes collected and the estradiol level on the trigger day - although the duration of the stimulation and gonadotrophin dose were relatively high. Supramaniam et al.'s meta-analysis [27] of 49 studies showed that the birth rate was lower in overweight and obese women than in women of normal weight (OR: 0.81; 95\%CI [0.74-0.89], $\mathrm{p}<0.00001$ ), with an elevated spontaneous miscarriage rate in obese women (OR: 1.52; 95\%CI [1.28-1.81], $\mathrm{p}<0.00001$ ). Lastly, in a recent literature review, Sermondade et al. found an OR of 0.85 (95\%CI [0.82$0.87]$ ) for the birth rate in obese women vs. women with a normal BMI [28]. In contrast, other investigators have failed to show an effect of BMI on pregnancy rates. Indeed, Legge et al. [29], Parent et al. [30], Ozekinci et al. [31] and Ben Haroush et al. [32] found that BMI was not associated with the $\mathrm{CP}$ rate. In a study of 2222 women of normal weight, 379 overweight women, and 27 obese women, Zhang et al. [33], found that the number of oocytes collected, the fertilization rate, the embryo cleavage rate, the number of "best" embryos, and the number of frozen embryos were all significantly lower in overweight women $(\mathrm{p}<0.001)$. In contrast, Zhang et al. found that the three weight classes had similar CP, birth and miscarriage rates. Similarly, Prost et al.'s study [34] of frozen blastocyst transfers did not find an effect of BMI.

Kudesia et al. [35] found significantly low pregnancy rates $(\mathrm{p}<0.001)$ in Ob1 women (OR: 0.89 95\%CI [0.83-0.95]) and Ob2-3 women (OR: $0.86 ; 95 \% \mathrm{CI}[0.79-0.93])$ - particularly in women with a polycystic ovary syndrome (PCOS, which was more frequent in Ob2-3) and in women with ovulatory dysfunction. In a population of women with PCOS, Bailey et al. [36] found that the birth rate per cycle was significantly lower in obese women (32.3\%, vs. $49.0 \%$ in women of normal weight; $\mathrm{p}=0.02)$ but not in overweight women $(68.4 \%$ vs. $49.0 \%$; $\mathrm{p}=0.39)$. The same was true for the CP rate. Rehman et al. [37] found a negative effect of PCOS (regardless of weight class), relative to women without PCOS. Our present results differed because the $\mathrm{CP}$ rates were similar in the $\mathrm{Ob} 1$ and Ob2 subgroups. Nevertheless, along women with PCOS (4\% of the NW group, $7.1 \%$ of the OW group and $21.3 \%$ of the Ob group in IVF/ICSI; respectively $5.2 \%, 8.6 \%$ and $30 \%$ in IUI), the CP rate was higher among overweight individuals (OR: 1.87; 95\%CI [1.81-1.93] for IVF/ICSI and 1.46; 95\%CI [1.39-1.53] for IUI) but lower among obese individuals $(0.71 ; 95 \% \mathrm{CI}$ [0.55-0.87] for IVF/ICSI and $0.74 ; 95 \% \mathrm{CI}$ [0.53-0.95 for IUI) and individuals of normal weight $(0.84 ; 95 \% \mathrm{CI}$ [0.81-0.87] for IVF/ICSI). It is noteworthy that in our study, women with PCOS were classified in the "ovulatory dysfunction" group (46\% of the women in the NW group with ovulatory dysfunction had PCOS, with $45 \%$ in the OW group and $78 \%$ in the Ob group in IVF/ICSI; the corresponding values were respectively $68 \%, 57 \%$ and $84 \%$ in IUI) or a "mixed infertility" group (respectively $34 \%, 40 \%$ and $14 \%$ of the women in the NW, OW and Ob groups in IVF/ICSI); this might explain the negative influence of obesity on the CP rate in these indications.

In our present analysis of both IVF and IUI cycles, male obesity only had a positive effect on the likelihood of pregnancy in women of normal weight, whereas this factor was negative in overweight and obese women; this finding suggests that the negative effects of male obesity and female obesity are additive. Our results are in line with the Mushtaq et al.'s meta-analysis [38], which evidenced an association between high male BMI and low CP and live birth rates in IVF/ICSI. It appears that male obesity mainly influences the birth rate, which is 
suggestive of paternal imprinting - perhaps on the placenta. Wang [39] did not evidence an effect of male overweight on the $\mathrm{CP}$ rate for woman of normal weight or overweight women. In the study by Tola et al. [40], male weight had no effect on the outcome for women of normal weight, as was the case in the present study.

In the present study, we assessed the influence of male and female tobacco use. Tobacco use in obese women had no impact in IVF/ICSI but was harmful in IUI. Lintsen et al. [40] showed a negative effect of tobacco use on IVF results (OR: 0.74; 95\%CI [0.63-0.87]), regardless of the indication (tubal, male, or unexplained infertility). It is possible that the higher level of ovarian stimulation in IVF/ICSI corrects the effects of tobacco use in obese women via hormone impregnation. In overweight and obese women, male tobacco use has a positive effect in IVF/ICSI but a negative effect in IUI. Male tobacco use has a harmful effect on sperm quality (oligo/asthenospermia), which is expressed more strongly in IUI than in IVF/ICSI, where the fertilization technique compensates for the sperm's impairments. In fact, ICSI might modulate the negative effect of female and/or male BMI on spermatozoid-oocyte fusion during fertilization [41]. In the present study, we observed positive effects of $\geq 5$ million spermatozoids inseminated in IUI (OR: 1.54; 95\%CI [1.35-1.73]) and IVF/ICSI (OR: 1.39; 95\%CI [1.15-1.63]) in obese women.

Concerning the data on the IVF/ICSI cycles, we noted a significantly higher total dose of gonadotrophin and a longer duration of stimulation in the Ob group. In obese women, Esinler et al. [42] showed that the total dose of gonadotrophin was elevated (by $361 \mathrm{IU}$ ), even though the number of oocytes retrieved and the number of metaphase II oocytes were significantly lower than normal. Maheswari et al. [25] noted that a total additional dose of $210 \mathrm{IU}$ was used in obese women. In the study by Dodson et al. [15], the total dose of gonadotrophin was higher in obese women, with a mean value of $551 \mathrm{IU}$ (95\%CI [226-876]; $<<0.001)$. This was explained notably by a longer duration of stimulation as the BMI rose (9.4 days in the obese group vs. 8.4 days in the non-obese groups; $\mathrm{p}=0.034$ ) [29]. In women with ovarian failure, the BMI also appears to be a key determinant of the pregnancy rate. Vural et al. [43] showed that the fertilization and CP rates were lower in obese women than in women with a normal BMI (fertilization: $64.4 \%$ vs. $82.3 \%$, respectively; $\mathrm{p}=0.04$; CP: $15 \%$ vs. $33.3 \%$; $\mathrm{p}=0.02$ ). In the same setting, the study by Maged et al. [44] evidenced an effect on the embryo implantation rate. In our study of IVF/ICSI cycles, we found that a low ovarian reserve had a positive effect in the $\mathrm{Ob}$ group and a negative effect in the OW group. Likewise, for women with a BMI $>30$, the number of cancelled cycles was $35 \%$ higher, as was the incidence of follicular atresia; this may have resulted from the follicle's more androgenic environment. In our study, there was no difference between the NW, OW and $\mathrm{Ob}$ groups with regard to the cancellation rate during stimulation. When we excluded all instances of "freeze-all" (which enables many couples to obtain a pregnancy after a frozen-thawed embryo transfer) and assessed only the cycles with fertilization and embryo culture failures, there were $130(21.3 \%)$ cancellations between retrieval and the transfer in the NW group, 64 (22.6\%) in the OW group, and 56 (31.6\%) in the Ob group. As in our study, Rabinson et al. [45] found that the type of protocol (long GnRH agonist or flexible GnRH antagonist) had no impact on the pregnancy rate in women with a BMI $>25(26.7 \%$ for women with a long $\mathrm{GnRH}$ agonist protocol, vs. $22 \%$ in women with a GnRH antagonist protocol; $p=$ non-significant). The numbers of mature oocytes and embryos obtained were significantly lower in obese women. Furthermore, our univariate analysis highlighted the importance of the number of embryos obtained for overweight and obese women. Van Swieten et al. [46] showed that the fertilization rates in obese women in IVF/ICSI were $45 \%$ lower than in women of normal weight. In a prospective study, Salha et al. [47] reported a fertilization rate of $46.2 \%$ for a BMI $>26$ vs. $61.3 \%$ for a BMI of between 18 and $25(\mathrm{p}<0.05)$. Lenoble et al. [48] reported low fertilization rates for a BMI $>25(48.8 \%$, vs. $52.7 \%$ for a BMI $\leq 25 ; \mathrm{p}<0.006)$. In the latter study, neither oocyte maturation nor embryo implantation appeared to be affected by the BMI; in contrast, the birth rate was significantly lower $(\mathrm{p}=0.02)$ when the BMI $>25(10.6 \%)$ was compared with a BMI of 18 to 25 (16.5\%). Ming et al. [49] noted a trend to perturbations during the first cleavages, which might explain the higher miscarriage rates in this population.

In contrast, the $\mathrm{CP}$ and live birth rates per insemination were significantly higher $(\mathrm{p}<0.05)$ for obese women undergoing IUI. With regard to the data on the IUI cycles, we noted poor sperm quality among the partners of overweight women but not among the partners of the women in the NW and $\mathrm{Ob}$ groups. The total dose of gonadotrophin and the duration of the stimulation were significantly higher in the Ob group, even though the estradiol level on the hCG day and the endometrial thickness were significantly lower in this group. These anomalies might be related to the pharmacokinetics of gonadotrophins (the FSH threshold, and the volume of distribution), hyperinsulinemia (and thus resistance to gonadotrophins), impaired estrogenic metabolism, and a low level of sex-hormone-binding globulin. In the present study, the CP and live birth rates in IUI were significantly higher in the $\mathrm{Ob}$ group than in the NW group (respectively 21.6 vs. $12.2 \%$ for CPs, and $17.7 \%$ vs. $9.3 \%$ for live births; $p<0.05$ for both). Our present results showed that sufficient ovarian stimulation, leading to an estradiol level $\geq 300 \mathrm{pg} / \mathrm{ml}$ on the trigger day (OR: 1.25 ; 95\%CI [1.06$1.44]$ ) and a two-follicle response (OR for monofollicular: $0.81 ; 95 \% \mathrm{CI}$ [0.67-0.95]) were two positive factors for CP. Likewise, $\geq 5$ million spermatozoids in IUI (OR: 1.54; 95\%CI [1.35-1.73]) was a positive factor, although this was difficult to achieve in men who smoked (OR: 0.38 ; 95\%CI [0.14-0.62]) and in overweight or obese women (OR: 0.46 ; 95\%CI [0.22-0.70] and 0.30; 95\%CI [0.14-0.46], respectively). As in an earlier study, we found that the first two insemination cycles were important for obtaining a pregnancy in obese women [16]. The management of IUI programs in obese women has rarely been studied, and the few published studies have given sometimes conflicting results. Balen et al. [50] did not find an influence of BMI on the biochemical pregnancy rate $(\beta \mathrm{hCG}<1000 \mathrm{IU} / \mathrm{l})(\mathrm{p}=0.363)$ or the ongoing pregnancy rate $(\mathrm{p}=0.828)$ in a population of women with anovulatory infertility. In a prospective study of 301 women in IUI programs, Isa et al. [51] did not find a significant difference in the pregnancy rate as a function of the BMI; indeed, the pregnancy rate was even significantly higher in obese women ( $13 \%$ for Ob2-3 and $9.52 \%$ for Ob1) than in women with a normal BMI (7.84\%). Souter et al. [52] studied the results of 1189 IUI cycles as a function of the BMI. A BMI $>25 \mathrm{~kg} / \mathrm{m}^{2}$ was associated with higher birth rates - particularly in the group with a BMI between 25 and $29.9 \mathrm{~kg} / \mathrm{m}^{2}$ (OR: $1.81 ; \mathrm{p}=0.01$ ). A similar trend was observed in the group with a BMI $>30(\mathrm{OR}: 1.8 ; \mathrm{p}=0.07)$. Souter et al. concluded that after adjustment of the gonadotrophin doses to counter the effect of obesity, the treatment efficacy is at least as good as in women with a normal BMI. The researchers notably suggested that these pregnancy rates were due to the correction of anovulation in this obese population, which had a high prevalence of anovulatory infertility at baseline $(28 \%$ in our study). However, we found that PCOS had a negative effect in obese women in IUI (OR: 0.74 ; $95 \%$ CI [0.53-0.95] and in IVF/ICSI (0.71; 95\%CI [0.55-0.87]).

The multivariate analyses of IVF/ICSI and IUI revealed differences in outcomes as a function of the technique used. Although young 
female age was a positive factor for pregnancy in IVF/ICSI, its impact was not significant in IUI. Surprisingly, female tobacco use and primary infertility (in obese women) were positive factors for CP in IVF/ICSI. This suggests that strong ovarian stimulation mitigates these usually poor prognostic factors. The availability of 5 or more embryos was a positive prognostic factor; this is logical and fits with the literature data. In contrast, female tobacco use, primary infertility and a monofollicular response to ovarian stimulation were negative prognostic factors in IUI, as reported elsewhere [14]. More than 5 million spermatozoids in IUI even appeared to be a negative factor in overweight women - as if overweight alone was enough to reduce the likelihood of pregnancy.

Obesity is an independent risk factor for miscarriage in the first trimester of pregnancy, as demonstrated by Wang et al.'s study [53] of 3586 women in IVF/ICSI. Compared with a group of women of normal weight, the $\mathrm{Ob} 1$ and $\mathrm{Ob} 2-3$ groups had a significantly lower birth rate (OR: 0.73; 95\%CI [0.57-0.96] and 0.5; 95\%CI [0.32-0.77], respectively). [54] In a study of 2660 women (5019 cycles) in IVF/ICSI, Fedorcsak et al. evidenced an elevated miscarriage rate in the normal BMI group $(2.9 \%)$, relative to the overweight group (4.4\%) and the obese group (3.9\%; $\mathrm{p}=0.04)$. Similarly, Bellver et al. [55] found a significantly higher miscarriage rate in obese women after oocyte donation $(38 \%$, versus $13 \%$ for non-obese women; OR: 1.53; 95\%CI [1.27-1.84]). Nevertheless, in a study of 6500 IVF/ICSI cycles published in 2010 [56], the same research group found similar miscarriage rates (around 17\%-21\%). Metwally et al. [57] reported a significantly elevated miscarriage rate in a group of obese women with spontaneous cycles or in IVF (OR: 1.52; 95\%CI [1.1-2.09]), and Thum et al.'s study of 8145 IVF/ICSI cycles [58] found a miscarriage rate of $53.3 \%$ for women with a BMI $>36$ and $23.6 \%$ for women with a BMI between 19 and 26 ( $\mathrm{p}=0.018$ ). In a study of 582 women in IVF/ICSI, Caillon et al. [59] noted that the miscarriage rate rose with the BMI. Kawwass et al. [12] also found low CP and birth rates in overweight women (OR: 0.97 and 0.95 , respectively) and in obese women (OR: 0.94 and 0.87 , respectively). In the latter study, only obese women showed an elevated miscarriage rate. In the present study, all three BMI groups had the same miscarriage rate, regardless of whether the women were in IVF/ICSI or IUI program; this absence of a difference might be due to a lack of statistical power. Maheswari et al. reported that a BMI $>30 \mathrm{~kg} / \mathrm{m}^{2}$ increased the risk of miscarriage (OR: 1.53 [95\% CI: 1.27-1.84], relative to a BMI $<30 \mathrm{~kg} / \mathrm{m}^{2}$ [25]. This increase in the risk of miscarriage might result from hyperinsulinemia, impaired luteal hormone bioactivity, and impaired leptin-mediated embryo-maternal dialogue in obese women. However, Pinborg et al.'s study [60] of a Danish cohort of 487 infertile couples in IVF did not evidence a significant difference in the miscarriage rate as a function of the BMI: $3.4 \%$ in the normal BMI group, $3.1 \%$ in the overweight group, and $5.1 \%$ in the obese group. The miscarriage rates in Pinborg et al.'s study are close to those observed in our study.

Even though the three groups in our study did not differ with regard to the CP and live birth rates, we consider that it is important to encourage women to lose weight and thus limit the risks related to ovarian stimulation, oocyte retrieval, and pregnancy [61]. Romanski et al. [62] evidenced a longer retrieval time and a need for higher doses of anesthetics in women with a BMI $>40$. In the group of women with $\mathrm{BMI} \geq 40 \mathrm{~kg} / \mathrm{m}^{2}, 14.1 \%$ required oxygen post-operatively (vs. $4.8 \%$ for women with a $\mathrm{BMI}<40 \mathrm{~kg} / \mathrm{m}^{2}$ ) but none required vasopressor injection or post-operative admission (Figures 1 and 2).

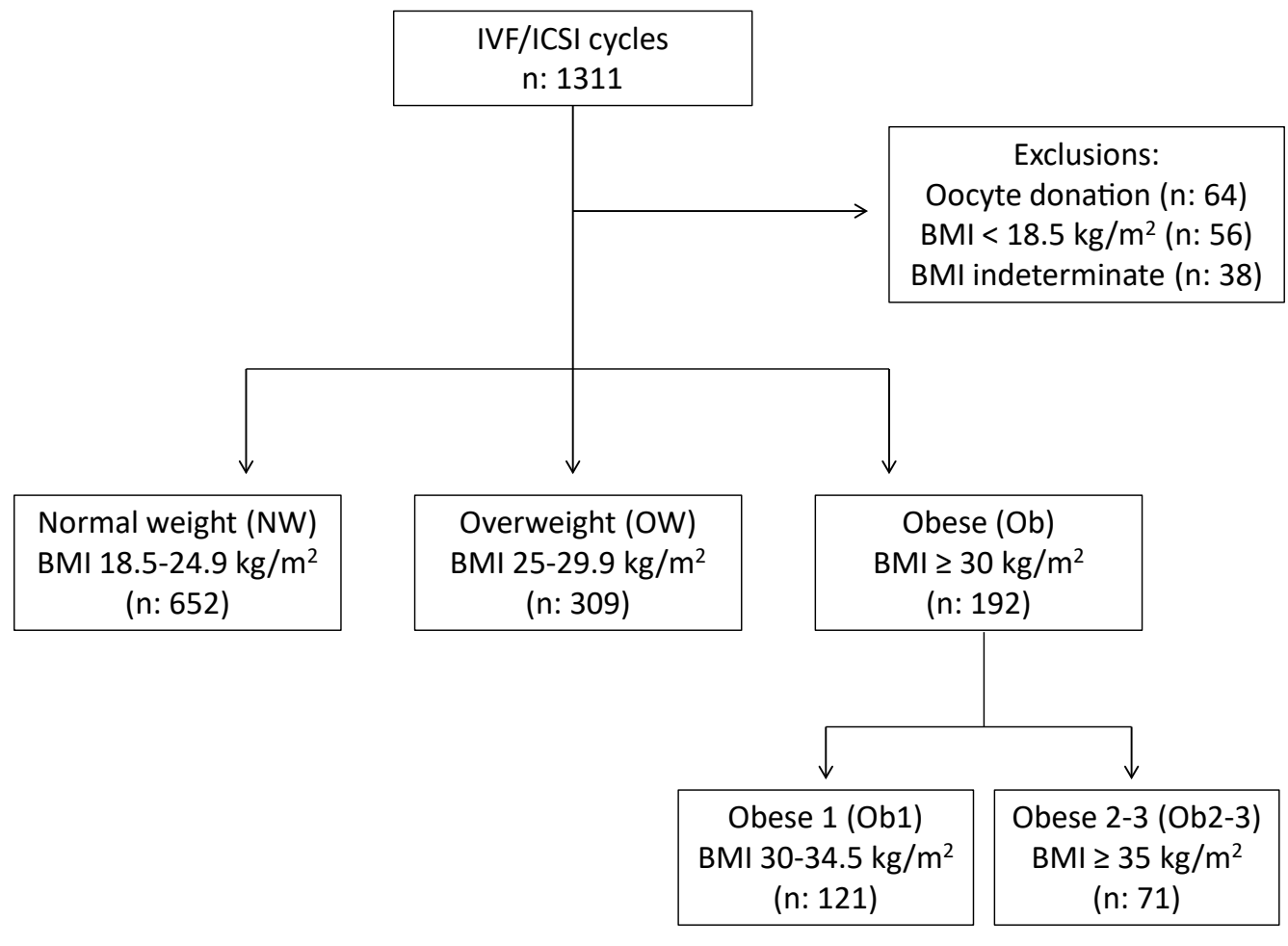

Figure 1. Flow chart for IVF/ICSI cycles

Legend: BMI: body mass index 


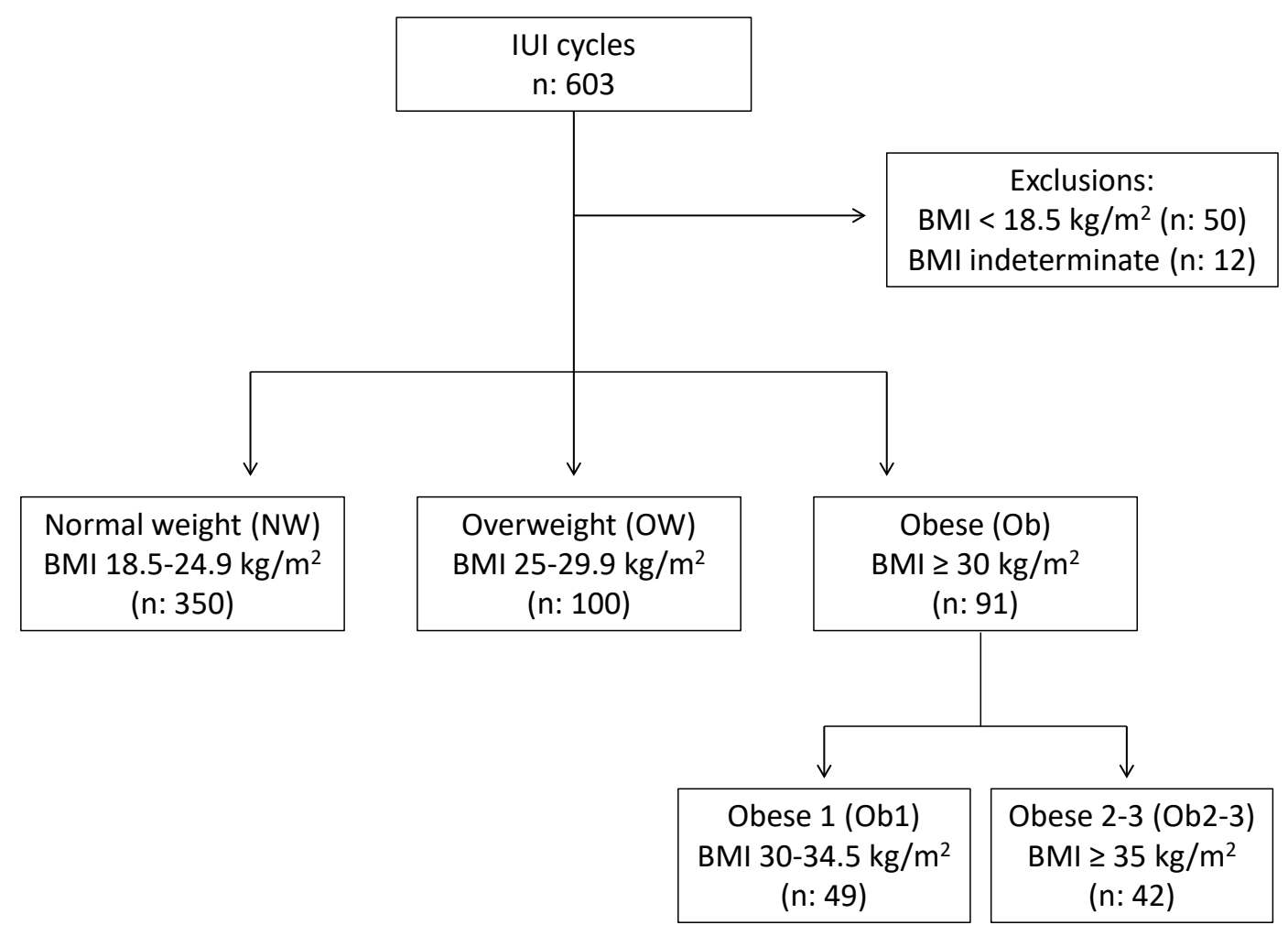

Figure 2. Flow chart IUI cycles

Legend: BMI: body mass index

\section{Limitations}

Firstly, its single-center retrospective design and small sample size limited the level of scientific proof. Secondly, sampling bias was present: the BMI groups differed significantly with regard to the proportions of the various etiologies of infertility. However, we chose to perform an intention-to-treat analysis and therefore did not exclude women with an age-related decrease in oocyte quality. Thirdly, we did not record the waist:height ratio, which is an index of excessive visceral fat accumulation that reduces fertility (due to lipotoxicity and the associated high free radical levels) [63].

\section{Conclusions}

Our results evidenced (i) higher $\mathrm{CP}$ and live birth rates in obese women in IUI, and (ii) the lack of an impact of BMI on CP and live birth rates in IVF/ICSI. According to international guidelines, infertile couples must be informed that the female obesity decreases the chances of pregnancy and increases the obstetric and neonatal risks. If allowed by the context and the woman's age, weight loss is to be encouraged because it should increase the spontaneous conception rate. Furthermore, this weight loss will diminish the risk of obstetric complications (such as gestational diabetes and preeclampsia) and fetal complications (such as macrosomia). So, should women be told to lose a significant amount of weight (as the European Society of Human Reproduction and Embryology recommends [64]) before they can be treated in an ART center?

\section{Disclosure Statement}

The authors report no conflicts of interest in relation to the present study

\section{Informed consent}

Informed consent was obtained from all individual participants included in the study

\section{Consent for publication}

The manuscript has been read and approved by all authors

\section{Availability of data}

The material contained in this manuscript has not been published, has not been submitted or is not being submitted elsewhere

\section{Funding}

Not applicable

\section{Authors' contribution}

Philippe Merviel: substancial contributions to the conception, design the work, the acquisition, analysis and interpretation of data, have drafted the work or substantively revised it. Head of the ART center

Anne-Solenn Jacamon: substancial contributions to the conception, design the work, the acquisition, analysis and interpretation of data, have drafted the work or substantively revised it

Sarah Bouée: substancial contributions to the conception, design the work, the acquisition, analysis and interpretation of data, have drafted the work or substantively revised it

Marie-Thérèse Le Martelot: the acquisition of clinical data 
Sylvie Roche: the acquisition of clinical data

Jean-Jacques Chabaud: The acquisition of clinical data

Hortense Drapier: the acquisition of biological data

Aurore Perrin: the acquisition of biological data

Damien Beauvillard: the acquisition of biological data. Head of the Reproductive Biology ART center

\section{Acknowledgements}

The authors thank David Fraser for their comments, suggestions and critical reading of the manuscript.

\section{References}

1. Zegers-Hochschild F, Adamson GD, Dyer S, Racowsky C, Mouzon J, et al. (2017) The International Glossary on Infertility and Fertility Care, 2017. Fertil Steril 108: 393-406. [Crossref]

2. Datta J, Palmer MJ, Tanton C, Gibson LJ, Jones KG, et al. (2016) Prevalence of infertility and help seeking among 15000 women and men. Hum Reprod 31: 21082118. [Crossref]

3. Slama R, Ducot B, Keiding N, Blondel B, Bouyer J (2012) The fertility of the couples in France. Bull Epidemiol Weekly 87-91.

4. Wise THE, Rothman KJ, Mikkelsen EM, Sørensen HT, Riis A, et al. (2010) An internet-based prospective study of body size and time-to-pregnancy. Hum Reprod 25: 253-264. [Crossref]

5. Hassan MAM, Killick SR (2004) Negative lifestyle is associated with a significant reduction in fecundity. Fertil Steril 81: 384-392. [Crossref]

6. Charles MA, Basdevant A, Eschwege E (2002) Prevalence of obesity in adults in France: the situation in 2000 established from the OBEPI Study. Ann Endocrinol (Paris) 63: 154-158. [Crossref]

7. Broughton OF, Moley KH (2017) Obesity and female infertility: potential mediators of obesity's impact. Fertil Steril 107: 840-847. [Crossref]

8. Silvestris E, de Pergola G, Rosania R, Loverro G (2018) Obesity as disruptor of the female fertility. Reprod Biol Endocrinol 16: 22. [Crossref]

9. Bellver J, Melo MAB, Bosch E, Serra V, Remohí J, et al. (2007) Obesity and poor reproductive outcome: the potential role of the endometrium. Fertil Steril 88: 446-451. [Crossref]

10. Kawwass JF, Kulkarni AD, Hipp HS, Crawford S, Kissin DM, et al. (2016) Extremities of body mass index and their association with pregnancy outcomes in women undergoing in vitro fertilization in the United States. Fertil Steril 106: 1742-1750.

11. Petersen GL, Schmidt L, Pinborg A, Kamper-Jørgensen M (2013) The influence of female and male body mass index on live births after assisted reproductive technology treatment: a nationwide register-based cohort study. Fertil Steril 99: 1654-1662. [Crossref]

12. Wang JX, Warnes GW, Davies MJ, Norman RJ (2004) Overweight infertile patients have a higher fecundity than normal-weight women undergoing controlled ovarian hyperstimulation with intrauterine insemination. Fertil Steril 81: 1710-1712. [Crossref]

13. Dodson WC, Kunselman AR, Legro RS (2006) Association of obesity with treatment outcomes in ovulatory infertile women undergoing superovulation and intrauterine insemination. Fertil Steril 86: 642-646. [Crossref]

14. Merviel P, Heraud MH, Grenier N, Lourdel E, Sanguinet P, et al. (2010) Predictive factors for pregnancy after intrauterine insemination (IUI): An analysis of 1038 cycles and a review of the literature. Fertil Steril 93: 79-88. [Crossref]

15. World Health Organization (2010) WHO laboratory manual for the examination and processing of human semen.

16. Terriou P, Sapin C, Giorgetti C, Hans E, Spach JL, et al. (2001) Embryo score is a better predictor of pregnancy than the number of transferred embryos or female age. Fertil Steril 75: 525-531.

17. Gardner DK, Lane M (1997) Culture and selection of viable blastocysts: a feasible proposition for human IVF? Hum Reprod Update 3: 367-382.

18. Steinkampf MP, Hammond KR, Nichols JE, Slayden SH (2003) Effect of obesity on recombinant follicle-stimulating hormone absorption: subcutaneous versus intramuscular administation. Fertil Steril 80: 99-102. [Crossref]
19. Luke B, Brown MB, Stern JE, Missmer ITS, Fujimoto VY, et al. (2011) Female obesity adversely affects assisted reproductive technology (ART) pregnancy and live birth rates. Hum Reprod 26: 245-252. [Crossref]

20. Kupka MS, Gnoth C, Buehler K, Dahncke W, Kruessel JS (2011) Impact of female and male obesity on IVF/ICSI: results of 700,000 ART-cycles in Germany. Gynecol Endocrinol 27: 144-149.

21. Zander-Fox DL, Henshaw R, Hamilton H, Lane M (2012) Does obesity really matter ? The impact of BMI on embryo quality and pregnancy outcomes after IVF in women aged $\leq 38$ years. Aus NZ J Obstet Gynaecol 52: 270-276.

22. Sneed ML, Uhler ML, Grotjan HE, Rapisarda JJ, Lederer KJ, et al. (2008) Body mass index: impact on IVF success appears age-related. Hum Reprod 23: 1835-1839.

23. Provost MP, Acharya KS, Acharya CR, Yeh JS, Steward RG, et al. (2016) Pregnancy outcomes decline with increasing body mass index: analysis of 239,127 fresh autologous in vitro fertilization cycles from the 2008-2010 Society for Assisted Reproductive Technology registry. Fertil Steril 105: 663-669. [Crossref]

24. van der Steeg JW, Steures P, Eijkemans MJ, Habbema JD, Hompes PG, et al. (2008) Obesity affects spontaneous pregnancy chances in subfertile, ovulatory women. Hum Reprod 23: 324-328. [Crossref]

25. Maheshwari A, Stofberg L, Bhattacharya S (2007) Effect of overweight and obesity on assisted reproductive technology - a systematic review. Hum Reprod Update 13 433-444. [Crossref]

26. Rittenberg V, Seshadri S, Sunkara SK, Sobaleva S, Oteng-Ntim E, et al. (2011) Effect of body mass index on IVF treatment outcome: an updated systematic review and metaanalysis. Reprod Biomed Online 23: 421-439

27. Supramaniam PR, Mittal M, McVeigh E, Lim LN (2018) The correlation between raised body mass index and assisted reproductive treatment outcomes: a systematic review and meta-analysis of the evidence. Reproductive Health 15: 34. [Crossref]

28. Sermondade N, Huberlant S, Bourhis-Lefebvre V, Arbo E, Gallot V, et al. (2019) Female obesity is negatively associated with live birth rate following IVF: a systematic review and meta-analysis. Hum Reprod Update 25: 439-451. [Crossref]

29. Legge A, Bouzayen R, Hamilton L, Young D (2014) The impact of maternal body mas index on in vitro fertilization outcomes. J Obstet Gynaecol Can 36: 613-619. [Crossref]

30. Parent C, Pigeyre M, Pleuvet A, Thomas P, Deruelle P, et al. (2016) Infertility: A key time to follow a medical nutritional management. Our experience on 78 patients. Gynecol Obstet Fertil 44: 218-224. [Crossref]

31. Ozekinci M, Seven A, Olgan S, Sakinci M, Keslin U, et al. Does obesity have detrimental effects on IVF treatment outcomes? BMC Women's Health 15: 61. [Crossref]

32. Ben-Haroush A, Sirota I, Salman L, Its WY, Tulandi T, et al. (2018) The influence of body mass index on pregnancy outcome following single-embryo transfer. $J$ Assist Reprod Genet 35: 1295-1300. [Crossref]

33. Zhang D, Zhu Y, Gao H, Zhou B, Zhang R, et al. (2010) Overweight and obesity negatively affect the outcomes of ovarian stimulation and in vitro fertilisation: a cohort study of 2628 Chinese women. Gynecol Endocrinol 26: 325-332. [Crossref]

34. Prost E, Reignier A, Leperlier F, Caillet P, Barriere P, et al. (2020) Female obesity does not impact live birth rate after frozen-thawed blastocyst transfer. Hum Reprod 35 : 859-865. [Crossref]

35. Kudesia R, Wu H, Cohn KH, Tan L, Lee JA, et al. (2018) The effect of female body mass index on in vitro fertilization cycle outcomes: a multi-center analysis. $J$ Assist Reprod Genet 35: 2013-2023. [Crossref]

36. Bailey AP, Hawkins LK, Missmer ITS, Correia KF, Yanushpolsky EH (2014) Effect of body mass index on in vitro fertilization outcomes in women with polycystic ovary syndrome. Am J Obstet Gynecol 211: 163. [Crossref]

37. Rehman R, Mehmood M, Ali R, Shaharyar S, Alam F (2018) Influence of body mas index and polycystic ovarian syndrome on ICSI/IVF treatment outcomes: A study conducted in Pakistani women. Int J Reprod BioMed 16: 529-534. [Crossref]

38. Mushtaq R, Pundir J, Achilli C, Naji O, KhalafY, et al. (2018) Effect of male body mas index on assisted reproduction treatment outcome: an updated systematic review and meta-analysis. Reprod Biomed Online 36: 459-457.

39. Wang X, Hao J, Zhang F, Li J, Kong H, et al. (2016) Effects of female and male body mass indices on the treatment outcomes and neonatal birth weights associated with in vitro fertilization/intracytoplasmic sperm injection treatment in China. Fertil Steril 106: 460-466. [Crossref]

40. Lintsen AME, Pasker-de Jong PCM, de Boer EJ, Burger CW, Jansen CAM, et al. (2005) Effect of subfertility cause, smoking and body weight on the success rate of IVF. Hum Reprod 20: 1867-1875. [Crossref] 
41. Keltz J, Zapantis A, Jindal S, Lieman H, Santoro N, et al. (2010) Overweight men: clinical pregnancy after ART is decreased in IVF but not in ICSI cycles. J Assist Reprod Genet 77: 539-544. [Crossref]

42. Esinler I, Bozdag G, Yarali H (2008) Impact of isolated obesity on ICSI outcome. Reprod Biomed Online 17: 583-587. [Crossref]

43. Vural F, Vural B, Çakıroğlu Y (2015) The role of overweight and obesity in in vitro fertilization outcomes of poor ovarian responders. BioMed Res Int 2015: 781543. [Crossref]

44. Maged AM, Fahmy RM, Rashwan H, Mahmood M, Hassan SM, et al. (2019) Effect of body mass index on the outcome of IVF cycles among patients with poor ovarian response. Int J Gynaecol Obstet 144: 161-166.

45. Rabinson J, Meltcer S, Zohav E, Gemer O, Anteby EY, et al. (2008) GNRH agonist versus GNRH antagonist in ovarian stimulation: the influence of body mass index on in vitro fertilization outcome. Fertil Steril 89: 472-474. [Crossref]

46. Van Swieten EC, Leeuw-Harmsen L, Badings EA, Linden PJ (2005) Obesity and clomiphene challenge test as predictors of outcome of in vitro fertilization and intracytoplasmic sperm injection. Gynecol Obstet Invest 59: 220-224. [Crossref]

47. Salha O, Dada $T$, Sharma V (2001) Influence of body mass index and self-administration of hCG on the outcome of IVF cycles: a prospective cohort study. Hum Fertil (Camb) 4: 37-42. [Crossref]

48. Lenoble C, Guibert J, Lefebvre G, Dommergues M (2008) Effect of women's weight on the success rate of in vitro fertilization. Gynecol Obstet Fertil 36: 940-944. [Crossref]

49. Ming L, Yuan C, Ping L, Jie Q (2015) Higher abnormal fertilization, higher cleavage rate, and higher arrested embryos rate were found in conventional IVF than in intracytoplasmic sperm injection. Clin Exp Obstet Gynecol 42: 372-375. [Crossref]

50. Balen AH, Platteau P, Andersen AN, Devroey P, Sørensen P, et al. (2006) The influence of body weight on response to ovulation induction with gonadotrophins in 335 women with World Health Organization group II anovulatory infertility. BJOG 113: 11951202. [Crossref]

51. Isa AM, Abu-Rafea B, Alasiri ITS, Binsaleh S, Ismail KH, et al. (2014) Age, body mass index, and number of previous trials: are they prognosticators of intra-uterineinsemination for infertility treatment? Int J Fertil Steril 8: 255-260. [Crossref]

52. Souter I, Baltagi LM, Kuleta D, Meeker JD, Petrozza JC (2011) Women, weight, and fertility: The effect of body mass index on the outcome of superovulation/intrauterine insemination cycles. Fertil Steril 95: 1042-1047. [Crossref]
53. Wang AC, Wang Y, Wu FX, Zhu DY (2017) Assessing predictors for the success of GnRH antagonist protocol in reproductive women in IVF/ICSI - in fresh cycles. Biomed Rep 7: 482-486. [Crossref]

54. Fedorcsak P, Dale PO, Storeng R, Ertzeid G, Bjercke S, et al. (2004) Impact of overweight and underweight on assisted reproduction treatment. Hum Reprod 19: 2523-2528. [Crossref]

55. Bellver J, Rossal LP, Bosch E, Zuniqa A, Corona JT, et al. (2003) Obesity and the risk of spontaneous abortion after oocyte donation. Fertil Steril 79: 1136-1140. [Crossref]

56. Bellver J, Ayllon Y, Ferrando M, Melo M, Goyri E, et al. (2010) Female obesity impairs in vitro fertilization outcome without affecting embryo quality. Fertil Steril 93: 447454.

57. Metwally M, Cutting R, Tipton A, Skull J, Ledger WL, et al. (2007) Effect of increased body mass index on oocyte and embryo quality in IVF patients. Reprod Biomed Online 15: 532-538. [Crossref]

58. Thum MY, El-Sheikhah A, Faris R, Parikh J, Wren M, et al. (2007) The influence of body mass index to in-vitro fertilisation treatment outcome, risk of miscarriage and pregnancy outcome. J Obstet Gynaecol 27: 699-702.

59. Caillon H, Freour T, Bach-Ngohou K, Colombel A, Denis MG, et al. (2015) Effects of female increased body mass index on in vitro fertilization cycles outcomes. Obesity Res Clin Pract 9: 382-388.

60. Pinborg A, Gaarslev C, Hougaard CO, Andersen AN, Andersen PK, et al. (2011) Influence of female bodyweight on IVF outcome: a longitudinal multicentre cohort study of 487 infertile couples. Reprod Biomed Online 23: 490-499. [Crossref]

61. Merviel complications ponction.

62. Romanski PA, Farland LV, Tsen LC, Ginsburg ES, Lewis EI (2019) Effect of class II and class IV obesity on oocyte retrieval complications and outcomes. Fertil Steril 111: 294-301. [Crossref]

63. Pasquali R, Gambineri A (2006) Metabolic effects of obesity on reproduction. Reprod Biomed Online 12: 542-551.

64. ESHRE Task Force on Ethics and Law, Pennings G, Dondorp W, de Wert G, Shenfield F (2010) Lifestyle-related factors and access to medically assisted reproduction. Hum Reprod 25: 578-582. [Crossref]

Copyright: (C2020 Merviel P. This is an open-access article distributed under the terms of the Creative Commons Attribution License, which permits unrestricted use, distribution, and reproduction in any medium, provided the original author and source are credited. 